University of Pennsylvania Carey Law School

Penn Law: Legal Scholarship Repository

Faculty Scholarship at Penn Law

$1-1-2012$

\title{
Estimating the Deterrent Effect of Incarceration using Sentencing Enhancements
}

David S. Abrams

University of Pennsylvania Carey Law School

Follow this and additional works at: https://scholarship.law.upenn.edu/faculty_scholarship

Part of the Criminal Law Commons, Criminology Commons, Criminology and Criminal Justice Commons, Law and Economics Commons, Law and Society Commons, and the Social Control, Law, Crime, and Deviance Commons

\section{Repository Citation}

Abrams, David S., "Estimating the Deterrent Effect of Incarceration using Sentencing Enhancements" (2012). Faculty Scholarship at Penn Law. 361.

https://scholarship.law.upenn.edu/faculty_scholarship/361

This Article is brought to you for free and open access by Penn Law: Legal Scholarship Repository. It has been accepted for inclusion in Faculty Scholarship at Penn Law by an authorized administrator of Penn Law: Legal Scholarship Repository. For more information, please contact PennlawIR@law.upenn.edu. 


\title{
Estimating the Deterrent Effect of Incarceration using Sentencing Enhancements
}

\author{
David S. Abrams* \\ University of Pennsylvania
}

January, 2011

\begin{abstract}
Increasing criminal sanctions may reduce crime through two primary mechanisms: deterrence and incapacitation. Disentangling their effects is crucial, since each mechanism has different implications for optimal policy setting. I use the introduction of state add-on gun laws, which enhance sentences for defendants possessing a firearm during the commission of a felony, to isolate the deterrent effect of incarceration. Defendants subject to add-ons would be incarcerated in the absence of the law change, so any short-term impact on crime can be attributed solely to deterrence. Using cross-state variation in the timing of law passage dates, I find that the average add-on gun law results in a roughly 5 percent decline in gun robberies within the first three years. This result is robust to a number of specification tests and does not appear to be associated with large spillovers to other types of crime.
\end{abstract}

JEL Classifications: J24, K14, K42

\footnotetext{
*The author would like to thank Liz Ananat, Jessica Cohen, Claudia Goldin, Michael Greenstone, Justin McCrary, Guy Michaels, Sendhil Mullainathan, Sarah Siegel, Jeffrey Smith, Catherine Thomas, and participants of the MIT Labor Lunch, University of Maryland Criminology and Economics Workshop, University of Chicago Applied Microeconomics Lunch, University of Chicago Crime and Punishment Workshop, and Harvard Law \& Economics Seminar for very helpful comments. Trevor Gallen and Jon Gillam provided excellent research assistance. The author's email is dabrams@law.upenn.edu.
} 


\section{Introduction}

How much does the threat of incarceration deter crime? The answer to this question is of crucial importance in formulating criminal sentencing policies. An increase in sentence length for any given crime may reduce the incidence of criminal acts by deterring potential offenders, but it also increases the length of time offenders are incarcerated and are hence unable to commit additional offenses. Each effect has different implications for our crime prevention and punishment system. Distinguishing between these two effects - the deterrence effect and the incapacitation effect - is one of the most challenging problems in the economics of crime. This paper seeks to isolate the deterrent effect of sentencing by exploiting variation in penalties induced by add-on gun laws. This approach adds to previous deterrence research and is the first to analyze a repeated natural experiment on a national scale.

Add-on gun laws stipulate sentence enhancements for defendants convicted of possessing of a firearm while committing a crime. This type of law grew popular in the United States in the 1970s and 80s, with 30 states adopting one of these laws by 1996 (Vernick and Hepburn, 2003). Add-on gun laws provide a unique set of natural experiments that can be used to distinguish the deterrent effect of incarceration from the incapacitative effect. The key to the approach in this paper is the fact that add-on laws apply only to defendants who would otherwise receive sentences of incarceration. Thus the short-term impact of an add-on gun law should be purely deterrent.

For concreteness, consider the change in the gun robbery rate between the month before and the month after an add-on gun law goes into effect, in a jurisdiction where 
robbery carries a sentence of 5 years and the add-on is 3 years. After the law change, criminals convicted of gun robbery will now receive 8 year sentences instead of 5 . If there is no deterrent effect of the add-on law, there will be no difference in the number of defendants newly incarcerated the month before the introduction of the add-on law and the month after. Thus, if there is a change in the number of gun robberies in the month after the law's introduction, it cannot be due to a change in incapacitation, and the change may be attributed to the deterrent effect of the increased sentence length.

There are several characteristics of add-on gun laws that make them ideal for isolating the deterrent effect of incarceration. First, they are generally only applied in cases where the underlying crime would merit a sentence of at least several years, which allows a reasonable period of time to detect the deterrent effect. Second, add-on laws were adopted in many different states, yielding many separate experiments for the analysis. This builds on previous studies of deterrence, which usually focus on a single state (see e.g. Loftin and McDowall, 1989; Kessler and Levitt, 1999). Finally, add-on laws were adopted in at least four decades, during which there was substantial variation in crime rates. The temporal and cross-sectional variation in adoption of add-on laws makes it possible to control for time trends and state fixed effects.

Understanding the impact of incarceration has grown more important over time as incarceration rates in the United States have grown by over $250 \%$ between 1980 and 2008. ${ }^{1}$ The total U.S. incarcerated population in 2008 stood at 2.4 million, with the U.S. having the highest incarceration rate worldwide (Walmsley, 2009). These vastly

\footnotetext{
${ }^{1}$ See the Bureau of Justice Statistics website for recent data on incarceration rates: http://www.ojp.usdoj.gov/bjs/
} 
increased numbers have led to recent interest in reexamining the efficacy of current policies.

The relative impact of incapacitation and deterrence are of first-order importance in understanding how to effectively reduce crime. If deterrence is very small, increasing sentence lengths would only reduce crime by taking potential offenders off the streets for longer periods of time. This is a very expensive proposition, with jailing costs around \$100/day (see e.g. Dilulio and Piehl, 1991; Waldfogel, 1993; Levitt, 1996).

Alternatively, if deterrence is substantial, then increasing sentences offers a relatively low cost means of reducing the incidence of crime. If tougher sentences make a potential criminal less likely to offend then the state reduces crime without bearing the cost of enforcing the penalties. This type of rationale may be found in much of the literature on the economics of crime, going back to Becker's initial work in the 1960's (Becker, 1968). The aim of this paper is to empirically estimate the magnitude of deterrence more accurately than has previously been possible.

One of the implications of Becker's model of crime is that the most cost-effective crime-fighting strategy is one with very large fines and low probabilities of detection. Risk-neutral potential criminals will be equally deterred as with lower fines and higher probability of detection, but the cost to society will be much lower. ${ }^{2}$ Of course this is only true if defendants can be made to pay the high fines. This is one of the reasons that incarceration is in such common use - the penalty must be credible. Similarly, if lengthy sentences (analogous to large fines) substantially decrease defendant likelihood of

\footnotetext{
${ }^{2}$ Polinsky and Shavell (1999) show that if disutility of imprisonment is less than linear in time, increasing policing and decreasing lengths of incarceration may be optimal. Their model would still imply a deterrent effect of increased incarceration, although smaller than if disutility of imprisonment is linear or greater than linear in time.
} 
committing crime, they should be a cost-effective way to reduce crime, perhaps even in conjunction with a decrease in policing.

A great deal of research has gone into empirically testing various aspects of economic models of crime. A full review of the literature on deterrence has been the subject of a number of review articles, with mixed conclusions. Nagin (1998) finds evidence for an overall deterrent effect in the criminal justice system, but believes more work is needed to better establish that increased sentences deter crime. Doob and Webster (2003) review a large number of papers by criminologists and a handful by economists and conclude that the lack of strong evidence for deterrence is widespread enough to conclude that there is a null effect. These coauthors along with Frank Zimring (Webster, Doob, Zimring 2006) take a skeptical view of Kessler and Levitt's 1999 paper, and its evidence for deterrence. ${ }^{3}$ Robinson and Darley (2004) take a somewhat more nuanced view that there are circumstances where increased sentences may deter, although they believe the magnitude is insufficient to influence policy decisions. Levitt and Miles (2007), in a wide-ranging piece, point to some of the economic studies that suggest there is evidence for deterrence, but conclude that more research on the topic is needed.

Some of the earliest empirical work by an economist on deterrence was by Isaac Ehrlich (e.g. Ehrlich 1981) and focused to a great extent on murder. Recent papers attempting to distinguish deterrence from incapacitation include Levitt (1998a) in which he infers the relative importance of incapacitation and deterrence (and finds support for the importance of both) by looking at the substitution between different crimes. Helland and Tabarrok (2007) investigate the effects of California's three strikes law and find a

\footnotetext{
${ }^{3}$ Some of the criticism seems to originate from a misunderstanding of the triple difference strategy in Kessler and Levitt (1999).
} 
decrease in arrests of around 20\% among felons with two strikes. Drago, Galbiati, and Vertova (2009) use a natural experiment in Italy that induced individual-level variation in sentencing to estimate a deterrence effect.

Several papers have used the discontinuity in sentencing at the age of majority to identify deterrence effects. Levitt (1998b) uses cross-state differences in the relative harshness of adult sanctions relative to those for juveniles. He finds that those states with larger jumps in punishment tend to have larger decreases in adult crime relative to juvenile. Hjalmarsson (2009) finds that offender perceptions of penalties change far less than actual changes at the age of majority, and finds little evidence of deterrence in selfreported data. Lee and McCrary (2009) use high frequency data from Florida to search for a discontinuity in offending around the $18^{\text {th }}$ birthday. They find a drop in crime of $2 \%$ around this discontinuity and suggest that part of the low response might be due to myopic behavior. Two other recent papers of note look not at sentence length, but rather prison conditions and find evidence for deterrence (Katz, Levitt, Shustorovich, 2003; Chen and Shapiro, 2007).

A number of studies have looked at changes in gun laws in individual jurisdictions (e.g. Britt, Bordua and Kleck, 1996; Loftin and McDowall, 1984). The mixed results found in those papers may be partially explained by heterogeneity in prosecutorial and judicial discretion, discussed in Tonry (1992) and Kessler and Piehl (1998).

This paper takes a similar methodological approach to Kessler and Levitt (1999) in which they make use of sentence enhancements in California enacted by the passage of Proposition 8 to estimate deterrence. In that paper, as in this, the authors separate 
deterrence from incapacitation by examining changes in short-term crime rates for serious offenses with lengthy underlying sentences. Kessler and Levitt estimate the magnitude of the three year deterrent effect to be $8 \%$.

Another paper that this one parallels is that of Marvell and Moody (1995) in which they examine the effect of gun laws on a range of outcomes. The authors assemble a data set on firearm sentencing enhancements and test their impacts using panel data on both prison populations and crime. The authors find little evidence for impact of these laws on either category of outcome.

Although making use of the same law changes, this paper differs substantially in methodology, outcomes of interest, and conclusions from Marvell and Moody. Most significantly, Marvell and Moody are estimating a combined effect of both deterrence and incapacitation, whereas this paper focuses on isolating the deterrent effect. Their regressor of interest is a dummy variable that is one any time after the adoption of an add-on gun law. Making use of this regressor, along with an unbalanced panel gives substantially higher weight to states with early adoption of add-on laws. One further methodological difference is that this paper uses difference in differences to estimate effects, whereas Marvell and Moody's specification for gun robberies identifies the effects from time series variation alone.

The strategy in this paper for estimating the impact of increased sentence length follows similar lines to some of the aforementioned studies, but differs in important ways. First, I use an event study methodology in order to make greater use of the temporal variations in the data. Second, conclusions drawn from this research are easily generalized due to the length and breadth of the data set used. The sample in this study is 
extremely representative of the country as a whole, since most states passed an add-on gun law at some point in the period investigated. It also uses a time series almost 40 years long, which lends strength to the belief that the findings are not location and time specific. Third, the primary type of crime examined, robberies, is of significant interest because of its relative prevalence and substantial negative impact. This study makes use of hand-cleaned data to get around the well-known data errors in the Uniform Crime Reports. Fourth, a great deal of the paper is spent testing alternate specifications in an attempt to fully explore the sensitivity of the findings to choices of specification. Carefully checking that estimations are robust is of particular importance in the crime literature where the data is often noisy, clear experiments are rare, and confounds are plentiful (Maltz and Targonski 2004). Finally, I attempt to address difficulties that affect many studies with one-time rule changes in calculating correct standard errors (Bertrand, Duflo, Mullainathan 2004). I do so by constructing placebo laws and estimate standard errors using a Monte Carlo simulation.

I find evidence for a deterrent effect of sentence enhancement in the form of addon gun laws. The preferred specification yields a statistically significant point estimate of a $5 \%$ reduction in gun robberies within 3 years of the add-ons. I run numerous alternate specifications to address a host of potential confounds and gain a more thorough understanding of the impact of add-on gun laws. These robustness checks include using alternate date specifications, separately testing the effect of mandatory minimum laws, using different functional forms, weighting and data aggregation, allowing for autocorrelation and trend breaks in the data, using triple differences, and calculating numerical standard errors from a Monte Carlo simulation using placebo laws. The results 
from these specifications support the central conclusion of a decrease in the gun robbery rate within the first three years of introduction of add-on gun laws.

According to the economic model of crime, add-on gun laws should impact all crimes committed with the use of a gun. Besides robbery, the other major crime for which data is widely available on firearm use is assault, which does not exhibit a significant response to add-on penalties. This may support the notion that assaults are often "crimes of passion" and that individuals who commit assaults are not welldescribed by the rational criminal model. However the data on assaults is substantially noisier than for robberies which biases the estimates toward zero and may account for the lack of a statistically significant effect.

A concern regarding the impact of sentence enhancements is of unintended spillover effects. If add-ons simply cause a shift from gun crimes to non-gun crimes, only looking at gun crimes will overstate the effect. I test for this possibility by examining outcomes for non-gun robberies, and find that there was a decrease there as well. I further test for another plausible crime substitute, burglary, where there also appears to be a decline following add-on gun laws. This suggests that rather than switching crimes in response to increased penalties, some potential criminals "go straight" instead.

The rest of the paper proceeds as follows. Section II provides a brief background on firearm sentencing enhancements and a description of the data. Section III presents the main specifications along with a discussion of potential interpretations and confounds. Section IV presents the main empirical results. In Section V a number of alternate specifications and robustness checks are discussed; Section VI concludes. 


\section{The History of Add-on Gun Laws and Data Description}

An add-on gun law, as used in this paper, is a state law which mandates enhanced prison sentences for defendants convicted of a felony who are further found to have used or been in possession of a firearm in the commission of the felony. These types of laws became popular in the 1970s with the aim of reducing armed crimes. Over 25 states currently have add-on gun laws in their statutes, with most states adopting the laws in the 1970s and 80s. Figure 1 shows the geographical distribution of the timing of add-on law adoption across states.

This paper presents an investigation into changes in crime rates around the introduction of add-on gun laws. There are two different dates that could be relevant in causing a response in crime rates and thus two different sources for the law changes. The first uses data obtained from Vernick and Hepburn (2003) on the date the add-on law became effective. ${ }^{4}$ Use of this date is premised on fully-informed criminals rationally responding to changes in penalties precisely when they occur. Alternatively, it is possible that the publicity and debate surrounding an imminent change in the law or uncertainty about the law's effective date had an impact on potential criminal behavior before the change actually occurred. Thus several specifications explore changes in criminal activity at the time of the date of passage of the add-on gun law. These data were collected by the author from state criminal codes and state legislative journals and are summarized in Table 1.

\footnotetext{
${ }^{4}$ This data is largely based on Marvell and Moody (1995) with a number of updates and corrections.
} 
Add-on gun laws are a prominent example of legislative efforts to reduce the incidence of crime beginning in the $1960 \mathrm{~s} .{ }^{5}$ Legislation leading to increased penalties was introduced in an attempt to deter potential criminals and incapacitate potential recidivists. Closely related to add-on gun laws, and also designed to curb crimes involving firearms, are mandatory minimum laws. These laws are distinct from add-on laws because they do not necessarily increase the sentence length for a given defendant, but only provide a lower bound on his or her sentence length. Identifying the deterrent effect of increased incarceration time using changes in behavior around the time of the introduction of mandatory minimums poses a relatively complex problem since in many cases the minimum does not bind. ${ }^{6}$ That is, in many states, the minimum sentence for armed robbery is longer than the mandatory minimum for gun crimes. Nevertheless, the introduction of mandatory minimum laws provides a good proxy for any state-specific unobserved characteristics which may be associated with both changes in the incidence of crime and the decision to introduce gun add-ons. For this reason, the introduction of mandatory minimums is included in the empirical specifications and permits improved identification of the deterrent effect of the add-on laws.

The Uniform Crime Reports (UCR), compiled by the FBI, contains the longest and broadest dataset on crime in the United States. ${ }^{7}$ The latest reports consist of data

\footnotetext{
${ }^{5}$ Around the same time, sentencing guidelines were introduced around the country. Their purpose was to standardize sentence lengths but they also led to more severe sentencing in many cases.

${ }^{6}$ I run specifications using mandatory minimum gun laws alone to check for a significant effect, but do not find evidence for one. The coefficients on the mandatory minimum dummy variables are provided in Table 2.

${ }^{7}$ Another substantial dataset frequently used to study the impact of criminal legislation is the National Crime Victimization Survey. This data set has some advantages over the UCR in that it may capture crimes that go unreported to the police. However the data does not include geographic identification and thus cannot be used in the current research. "State codes are not available in the National Sample because
} 
collected from nearly 17,000 law reporting agencies, a number that has increased substantially over time. The increase in reporting agencies within each state poses an empirical challenge. Including all agencies reporting in a given time period will lead to a substantially unbalanced panel: later dates would receive much more weight. Thus for the main specifications, I construct a set of the 500 most populous agencies that report data for the full sample range (1965 - 2002). Twenty-one agencies are added to this data set for a total of 521 to ensure that every state is represented by at least 3 agencies. ${ }^{8}$

The uniform crime reports are known to contain substantial numbers of data errors, particularly at the agency level (Maltz and Targonski, 2004). Part of the data cleaning process required examination and correction of the data by hand, which necessitated limiting the data to the most populous agencies as described above. The data set used covers approximately $40 \%$ of the contemporary US population. I also use an alternate specification where data is aggregated to the state level. This has the advantage of being somewhat less noisy, but the difficulty that the number of agencies encompassed by a state varies over time.

There are several different types of data within the UCR including reported offenses, unfounded offenses, offenses cleared (cases in which arrests are made), and juvenile offenses cleared. In this study, I use reported offenses rather than arrests as the primary measure of the incidence of crime. This choice is made to try to address the concern that policing might be modified to focus on gun crimes in response to or contemporaneous with the introduction of add-on gun laws. A modification in policing

of confidentiality restrictions" (BJS 1998). City level files are available for 26 major cities for the years 1972-1975. These were not used due to the short time span available.

${ }^{8}$ There is one exception to this rule. There were only two districts in Vermont that reported for the full time period. 
behavior in response to legislative changes would be reflected in the number of offenses cleared and complicates the task of isolating the responsiveness of criminal activity to the new law. There may also be a change in crime reporting behavior in response to a law change or the ensuing publicity. To address this concern, this paper makes use of reported crimes rather than arrests. This way, even if there are contemporaneous policing changes, the impact on reported crimes should presumably be less sensitive to law changes than policies.

Within each category of offenses there are counts by reporting agency and by type of offense. Important to this study is the fact that, since 1965, counts of robberies and assaults have been distinguished by type of weapon involved. Reported gun robberies are the primary focus of this study due to data availability and the presumption that they are more likely to be "economic crimes" than assaults. ${ }^{9}$

\section{Methodology}

The empirical challenge is to isolate the effect of add-on gun laws, estimate their impacts, and try to minimize the possibility that estimates result from something other than deterrent effects of the laws. With this in mind I adopt an event study methodology for most specifications, which takes advantage of the variation in adoption date and

\footnotetext{
${ }^{9}$ Definitions from the Uniform Crime Reports:

Robbery - The taking or attempting to take anything of value from the care, custody, or control of a person or persons by force or threat of force or violence and/or putting the victim in fear. Separate counts are included for Firearm Robbery (i.e., any firearm is used as a weapon or employed as a means of force to threaten the victim or put him in fear).

Assault - An unlawful attack by one person upon another. Firearm Assault includes all assaults wherein a firearm of any type (e.g., revolver, automatic pistol, shotgun, zip gun, rifle, etc.) is used or its use is threatened.
} 
magnitude of add-on gun laws across states. I perform various falsification checks, including testing the date of law adoption versus the effective date, using placebo implementation dates, adding further controls, and restricting the data set. I test several models allowing for variation in the immediacy of impact of the law. I test several different outcomes: gun robberies, gun assault, non-gun robberies, and burglaries. I control for lagged prison population data, police population share, economic variables, and demographic variables.

The goal here is to identify the deterrent effect of incarceration, separate from incapacitation. Thus it is necessary to distinguish between changes in crime rates following the introduction of add-on laws caused by increased spells of incarceration from crime rate changes due to the fact that some potential offenders may have been deterred. This is done by restricting attention to crime rates within a short period immediately following the introduction of the add-on law.

The logic is as follows: Assume the minimum sentence for the underlying crime prior to the add-on was $x$ years and the add-on increases it by $y$ additional years. Within the first $x$ years after the law change there will be no effective change to incapacitation: all offenders sentenced in this period after the law change would have been incapacitated under the old law as well. Thus any change in crime rates in the first $x$ years cannot be due to incapacitation, and may be interpreted as a deterrent effect.

An important question, therefore, is of the appropriate value of $x$, the previous minimum sentence for the underlying crime. An estimate of three years was found as follows: Data on the minimum and maximum sentence for $1^{\text {st }}$ degree robbery (or its equivalent) was collected from state statutes for 47 of the 50 states (Figure 2). The mean 
minimum sentence length is 5.5 years and the median 5 years. For the maximum the numbers are 16.5 and 13.5 years, respectively. It is possible that some defendants serve less than the minimum time, receiving time off for good behavior (although truth-insentencing laws have reduced the likelihood of this happening over time). Ideally, one would prefer an empirical distribution of time served by state, but no such data set exists for the required years. The best empirical data on actual time served comes from the National Corrections Reporting Program, which is consistent with the three year figure. A three-year time span was hence chosen as a conservative estimate of the time during which those prisoners prevented from reoffending by incarceration would have been removed from the set of potential offenders independent of the introduction of an add-on gun law. ${ }^{10}$

The key identifying assumption in this paper is that add-on gun law adoptions are exogenous. Although most add-on gun laws were enacted in the 1970s, due to the previously-discussed national trends, the particular timing in a state is to a large degree random due to the vagaries of the political process within each state. This assumption plays a critical role in allowing the empirical tests to distinguish between general trends in crime rates in a given state and changes in behavior that are attributable to the introduction of the add-on law.

In order to further investigate the plausibility of this assumption, I collected additional data from newspapers. While it is difficult to establish complete randomness in the timing of law changes, there is some evidence to this point. Often legislative activity on crime-related issues is spurred by idiosyncratic events, like a particularly notorious crime. Newspaper data was collected in order to investigate whether this was a

\footnotetext{
${ }^{10}$ To be even more conservative, most of the analysis is also performed for one and two year time spans.
} 
frequent impetus for add-on gun laws. There is scant digitally searchable newspaper data available before the 1990's, yielding only 6 newspapers from 4 states with articles within a year of the law change. Although the small sample size makes it difficult to draw strong conclusions, it is informative to note that articles in 2 of the 4 states point to specific, notorious crimes as spurring the introduction of legislation. ${ }^{11}$

\section{A. Central Specification}

The initial test for the impact of add-on gun laws is a simple difference in

difference,

$$
y_{a t}=\beta_{\text {Addon }}{ }_{s t}+\lambda_{s}+\gamma_{t}+x_{s t}+m m_{s t}+\varepsilon_{a t}
$$

Here $\mathrm{y}_{\mathrm{at}}$ is the outcome of interest, namely a per capita crime rate, or log per capita crime rate. The variable Addon $_{\mathrm{st}}$ is a dummy that is one in states with an add-on gun law in force, within $\mathrm{n}$ years of the add-on date (where $\mathrm{n}$ varies across different specifications), and zero otherwise. ${ }^{12} \lambda_{\mathrm{s}}$ allows for permanent differences across states in crime rates (state fixed effects). Any national trends in crime will be absorbed into the year dummies $\left(\gamma_{t}\right)$. Potentially important time varying state characteristics are controlled for with the vector $\mathrm{x}_{\mathrm{st}}$. Controls include poverty rate, unemployment rate, racial composition, age composition, lagged police population share, and lagged imprisoned

\footnotetext{
${ }^{11}$ While it is difficult to establish complete randomness in the timing of law changes, there is some evidence to this point. Often legislative activity on crime-related issues is spurred by idiosyncratic events, like a particularly notorious crime. Newspaper data was collected in order to investigate whether this was a frequent impetus for add-on gun laws. There is scant digitally searchable newspaper data available before the 1990's, yielding only 6 newspapers from 4 states with articles within a year of the law change. Although the small sample size makes it difficult to draw strong conclusions, it is informative to note that articles in 2 of the 4 states point to specific, notorious crimes as spurring the introduction of legislation. ${ }^{12}$ Since there are only two examples of repeals of add-on gun laws (California in 1977 and Tennessee in 1989) there will be tremendous autocorrelation in this variable. This makes standard errors prone to potential underestimation, as discussed in Bertrand, et al (2004). Both clustering standard errors by state and estimating standard errors using placebo laws are used to correct this problem.
} 
population. ${ }^{13}$ They also include a dummy for whether the state has a mandatory minimum law in force $\left(\mathrm{mm}_{\mathrm{st}}\right)$. The coefficient $\beta$ signifies the impact of the add-on gun law. Errors $\left(\varepsilon_{\mathrm{at}}\right)$ are allowed to be heteroskedastic and correlated within states. Thus robust standard errors are clustered at the state level and population-weighted.

One potential shortcoming of the specification in (1) is that it doesn't allow for state-specific trends in crime that could impact a state's likelihood of adoption of an addon gun law. Adding these trends reduces the burden of exogeneity of the add-on laws: now the timing must simply be exogenous once state-specific crime trends are accounted for. The following specification adds the state-time trends $\left(\omega_{\mathrm{s}} \mathrm{t}\right)$ :

$$
y_{a t}=\text { BAddon }_{s t}+\lambda_{s}+\gamma_{t}+\omega_{s} t+x_{s t}+m m_{s t}+\varepsilon_{a t}
$$

This specification is also estimated using robust, population-weighted errors.

\section{B. Event Study}

To obtain a more precise understanding of the impact the add-on gun laws have year-by-year after their effective dates, it is useful to group agencies together according to the time period relative to the add-on date in their state. This results in an event study methodology similar to that employed by Jacobson, Lalonde, and Sullivan (1993) in order to identify earnings losses of displaced workers:

$$
y_{a t}=\sum_{i \geq-n} \beta_{i} D_{s t}^{i}+\lambda_{s}+\gamma_{t}+\omega_{s} t+x_{s t}+\varepsilon_{a t}
$$

The outcome as before is a measure of the crime rate at the agency level, and $\lambda_{\mathrm{s}}, \gamma_{\mathrm{t}}, \omega_{\mathrm{st}}$, $\mathrm{x}_{\mathrm{st}}$, and $\varepsilon_{\mathrm{at}}$ are as described above. The major distinction is that now there are multiple variables of interest, the $\beta_{\mathrm{i}}$ which indicate the impact of the add-on gun law at various

\footnotetext{
${ }^{13}$ Data for control variables were kindly made available by John Donohue.
} 
different times relative to the law's effective date. The $\mathrm{D}_{\mathrm{st}}{ }^{\mathrm{i}}$ are dummy variables that are 1 in state $\mathrm{s}$ if period $\mathrm{t}$ is exactly i periods after the effective date in that state, and zero otherwise. For example, in Arkansas the add-on year is 1981, so the $\mathrm{i}=3$ dummy will be 1 in 1984. The relative time index, i, may take on negative values to allow for any potential effects prior to the add-on date. This methodology is powerful in that it conveys a lot of information about the dynamics of the response to the add-on gun laws.

\section{Triple Difference}

The magnitude of the add-on sentence is another source of variation that can be exploited to further assess the deterrent effect of these laws. I interact the magnitude of the add-on with the timing dummies in a triple difference specification:

$$
y_{a t}=\phi \text { Addon }_{s t} * \text { Term }_{s}+\beta \text { Addon }_{s t}+\theta \text { Term }_{s}+\lambda_{s}+\gamma_{t}+x_{s t}+m_{s t}+\varepsilon_{s t}
$$

One would expect a greater deterrent effect in jurisdictions with greater add-on penalties. I test for this by estimating the coefficient on the interaction of the sentence term and add-on timing dummy.

\section{Lagged Dependant Variables}

Thus far all models presented have made the assumption that crime is determined by contemporaneous variables, or lags of regional characteristics, such as prison population. It certainly seems plausible, however, that current levels of crime could be impacted by previous levels of crime. For example, a high level of crime in period t-1 could lead to a change in police vigilance, a quantity that is not readily quantifiable. This in turn could lead to a decrease in crime in period t. Another story which also leads to 
this sort of structure would be one where previous levels of crime are informative to prospective criminals in a way that is not fully accounted for in the control variables. Higher levels of crime in period t-1 could indicate greater likelihood of success, and thus a higher level of crime in period t. We can express this model with a lagged dependant variable as follows:

$$
y_{s t}=\rho y_{s t-1}+\text { Bdddon }_{s t}+x_{s t}+m_{s t}+\lambda_{s}+\gamma_{t}+\varepsilon_{s t}
$$

The addition of the lagged dependant variable complicates the estimation procedure, relative to the models previously discussed. In particular, the fixed effect estimator thus far employed will be biased in the presence of a lagged dependant variable. This intuitively must be so since by the definition of a fixed effect, the lagged endogenous variable would be correlated with the error term. Given this difficulty, we follow the estimation procedure outlined in Arellano and Bond (1991).

First we may reinterpret all variables as deviations from the period means. This eliminates $\gamma_{t}$. Next, take the first difference of equation (5) (first aggregating all variables in state $\mathrm{s}$ at time $\mathrm{t}$ into $\left.\mathrm{D}_{\mathrm{st}}\right)$ :

$$
y_{s t}-y_{s t-1}=\rho\left(y_{s t-1}-y_{s t-2}\right)+\beta\left(D_{s t}-D_{s t-1}\right)+\left(\varepsilon_{s t}-\varepsilon_{s t-1}\right)
$$

Ordinary least squares estimation will be inconsistent since the lagged dependant variable will be correlated with the error term through common period t-1 terms. Thus an instrumental variables approach is necessary to produce consistent estimates. Arellano and Bond propose using lagged values of the dependant variable and the other regressors as the instruments for the first differences. Their use requires the identifying assumption that $\mathrm{k}^{\text {th }}$ lag may be used as an instrument only if there is no $\mathrm{k}^{\text {th }}$ order serial correlation. 
As in Arellano and Bond (1991), I make use of the GMM procedure to optimally take advantage of this identifying assumption. ${ }^{14}$

Since the validity of the GMM procedure crucially hinges on the identifying assumptions, they must be tested. An Arellano-Bond test for autocorrelation in panel data is used to test the assumption of serial correlation for different orders. Further, a test of overidentifying restrictions that is robust to heteroskedasticity is also performed.

\section{E. Change in Slope}

Thus far most of the specifications have focused on the coefficient on addon $_{s t}$, i.e. the difference in means before and after add-on gun laws. This choice has been made because a shift in mean crime rate is what the economic theory of crime predicts as the response to an increase in sanctions. However, one could certainly incorporate noninstantaneous information transmission which would lead to both a change in mean of crime rates and a change in time trends relative to a change in sanctions, represented by Equation 7.

$$
y_{a t}=\text { BAddon }_{s t}+\text { Adddon }_{s t} * \text { relyr }+\lambda_{s}+\gamma_{t}+\omega_{s} t+x_{s t}+m m_{s t}+\varepsilon_{a t}
$$

In fact, it is possible that the response to this policy change will not be instantaneous, and a more accurate representation would include a higher order terms of relative time to allow for adjustment to the new regime. To estimate this type of model one would simply need to modify Equation 7 by adding a polynomial in time relative to the add-on gun law effective date.

\footnotetext{
${ }^{14}$ There is one further assumption that is made, namely the standard assumption about the exogeneity of the other control variables being used for instruments.
} 


\section{Empirical Findings}

\section{$\underline{\text { A. Main Results }}$}

The first empirical results are from a regression of reported log gun robberies per capita on post add-on dummies, using the specification in Equation (1). Table 2 presents the results, with each column representing a separate regression. The log specification is preferred because it counts equivalent relative declines in per capita gun robberies equally. "Balanced panel" indicates that data points were included only if they were within 7 years prior to, or 6 years after the effective date for an add-on law. This is the maximum range of data that is available for all states that passed add-on laws. In half of the specifications the data is restricted to years after 1974 due to the fact that there is a discontinuity in several variables in a large number of agencies in 1975 in the UCR data. ${ }^{15}$ Panels A, B, and C differ in the number of years included in coding the post addon dummy. For example, in panel B, the add-on law dummy is one for the first two years following the add-on law effective date and zero otherwise. All errors reported allow for intra-state correlation and are weighted by state population. All specifications included state and year effects, and the controls discussed in section III.

Log per capita crime rate is the preferred dependant variable in this paper and this preference may be illustrated by the following example. Assume Miami has a pre-gun law level of 200 gun robberies per 100,000 residents and Phoenix has a pre-gun law level of 100 gun robberies per 100,000 residents. We might believe that the severity of the impact of a marginal crime decreases with level of crime, so a reduction from 100 to 50

\footnotetext{
${ }^{15}$ Staff members at the National Archive of Criminal Justice Data, which houses the publicly available UCR data set, were unable to account for this break in the data.
} 
gun robberies per 100,000 residents is more meaningful than one from 200 to 150 per 100,000 residents. If this belief about social preferences is accurate, it is appropriate to focus on the logarithm of the per capita rate of gun robberies as the outcome of interest. I also run regressions using per capita crime data as the dependant variable. These results are reported in part $\mathrm{C}$ of Section $\mathrm{V}$.

Across specifications there appears to be a consistent finding that gun robbery rates decline after add-on gun laws go into effect. The impact is insignificant in the first year, but is significant at the $1 \%$ level after two or three years. The coefficients in Table 2 yield an estimate of the magnitude of the impact of the impact. Although the coefficients vary somewhat across specifications, there is a decline of $6-14 \%$ within the first two years and 5-18\% within the first three years of introduction of the law. In the preferred specification, which is the most conservative, with a balanced-panel restricted to post-1974 data and including state-specific time trends, there is an impact which seems to level off to $6 \%$ within two years, and $5 \%$ within three years. Note that the addition of state-specific time trends does not affect the coefficient substantially. This provides some support for the notion that the timing of add-on gun laws is exogenous. ${ }^{16}$

In order to gain more information on the timing of the impact of the law change, I estimate equation (3) using log per-capita gun robberies as the dependant variable. The results, reported in Table 3 and Figure $3^{17}$, support the findings discussed above. Gun robberies rates (both with and without controlling for state trends) are fairly stable in the years preceding implementation of an add-on gun law, then decline for approximately

\footnotetext{
${ }^{16}$ Wolfers (2006) notes that adding state-specific time trends in Friedberg (1998) causes a large change in coefficients and casts some doubt on the assumption that at-will divorce law passage was exogenous.

${ }^{17}$ The absolute values on the $y$-axis of this and other figures are not meaningful in themselves (since they come from regressions that include a number of regressors with non-zero means) but the changes are.
} 
three years and then level out. One surprising feature of Figure 3 is that it appears that the downward trend may begin slightly before the effective date. I discuss the timing of the impact of the law in part A of Section V.

The evidence from UCR data on gun robberies supports the notion that criminals are deterred by the implementation of add-on gun laws. There are a number of important confounds that could be belie this interpretation, and they are addressed at length in Section V. But it is important to take note of the strength of the evidence presented here. By using panel data with state and time fixed effects, I have attempted to rule out that spurious results could be obtained due to an overall national time trend in crime, or crosssectional endogeneity in passage of add-on gun laws. Adding state trends increases the strength of the exogeneity assumption by ruling out endogenous response in law passage not just to levels, but also to state trends in crime. Making use of timing dummies relative to the law effective date allows for the detection of the dynamic response of crime relative to implementation of the law.

\section{B. Gun Assaults and Total Assaults}

If the economic model of crime is correct, one should observe a deterrent effect of add-on gun laws on all types of gun crimes. The other category of crime for which weapon type is reported in the UCR is assault. Assaults are often considered to be "crimes of passion" and thus may not be as well described by the economic model of crime. Nevertheless, one might expect that some fraction of assaults do have an indirect economic motive, or at least respond to changes in penalties. 
Using UCR data on reported gun assaults, I test for a deterrent effect of add-on gun laws on gun assaults, and find no significant effect. Table 4 reports results from specifications described by equations (1) and (2) and Figure 4 displays coefficients from the specification in equation (3). It is difficult to discern much of a pattern around the add-on law effective date from the figure. However, Table 4 tells a somewhat different and intriguing story. Add-on laws do not appear to have a significant effect on gun assaults within one, two or three years of the effective date. Still, almost all of the coefficients on gun assaults are negative, suggesting weak deterrence on gun assaults. Assault data in the UCR has substantially greater intertemporal and cross-sectional variation than robbery data, and the null result may simply be due to inability to extract a signal from the noise. The evidence suggests that assaults may be weakly deterred by increased penalties, but the findings are not statistically significant.

\section{Non-gun Robberies and Burglaries}

While economic theory clearly predicts a negative relationship between the presence of add-on gun laws and gun crimes, the prediction is less clear for non-gun crimes. Add-on gun laws will increase non-gun crimes if guns and other weapons are good substitutes and criminals shift towards other weapons or types of crime as the cost of using a gun increases. Alternatively, add-on gun laws may reduce non-gun crimes if individuals choose whether or not to be a generalist career criminal based on the total expected returns of criminal and alternative careers. Decreased expected returns due to add-on gun laws could lead criminals to shift into the legitimate sector and thus reduce levels of all types of crime. 
Data from both non-gun robberies and burglaries appear to support the career criminal model over the substitution model. First I investigate the effect of add-on gun laws on total robberies and robberies using weapons other than guns, with results presented in Tables 5 and 6 and Figure 5. There is no evidence in any of the regressions for the substitution model, as almost all estimates for the short-term impact of add-on gun laws on non-gun robberies and total robberies are negative. Not surprisingly, the effect of non-gun robberies is not as substantial (or significant) as that on gun robberies, with the preferred specification yielding a three year impact of $-3 \%$. This is the same point estimate obtained for total robberies, although most specifications yield estimates with slightly higher magnitudes for total robberies. Turning to the relative year dummy specification reveals a similar temporal pattern, but of smaller magnitude, for both nongun robberies (Figure 5) and total robberies (not reported) as for gun robberies.

It appears that criminals do not substitute other weapons for guns in order to commit robberies, but perhaps they substitute different crimes for robbery when the price of using a gun increases. Burglary is the closest substitute for robbery in the Uniform Crime Reports. Table 7 reports a statistically significant $5 \%$ decline in burglaries per capita in the three years following introduction of an add-on gun law (in the preferred specification). Turning to the event study methodology (Figure 6) provides evidence of a similar temporal pattern relative to the add-on date for burglaries, as for gun robberies and non-gun robberies.

It appears that a number of different types of crime are being impacted by the implementation of add-on gun laws. As discussed above, these results support the career criminal hypothesis. There are also other potential explanations for the similar time 
pattern of crime reduction. For example, misclassification of some fraction of gun robberies as non-gun robberies could lead to these results. Other possibilities could include a contemporaneous law enforcement change (like a broad crackdown on crime) or a mean-reverting crime process with endogenous legislative implementation of add-on gun laws. These potential confounds and a number of specification checks are discussed in Section V.

\section{Addressing Potential Concerns}

\section{A. Timing of the Decline in Crime}

Thus far I have presented evidence for a deterrent effect of add-on gun laws, leading to a decrease in gun robberies per capita of about $5 \%$ within the first 3 years of passage. One potential concern regards the timing of the decrease in crime: there is a slight (statistically insignificant) decline in gun robberies prior to the effective date of the add-on law, even when controlling for state-specific time trends (Figure 3). Although the regression results indicate a significant decrease in crime after the effective date of the law change, there may be concern that states pass laws in response to a run-up in crime, and the decline is simply reflecting mean reversion in crime rates. The fact that a decline in crime prior to the effective date of the law persists even when state trends are included casts some doubt on this explanation. This still leaves open the possibility that laws are passed in response to changes in the crime trend. Anecdotal data from newspaper articles presented provides some evidence that the exact date of law change is largely 
stochastic. ${ }^{18}$ In order to further address this concern, specifications using higher order polynomials for state time trends were tested with results similar to those presented (see discussion below and Table 8).

Another possible interpretation of the slight decrease in crime pre-law change is that potential offenders learn about the law through ongoing public debate and discussion and modify their behavior in anticipation of the law change. The process by which potential offenders learn about criminal sanctions is not well-studied. There is some evidence (Pogarsky, et al. 2004; Tunnell 1996) that potential criminals often have very noisy information about penalties they may face. Other work (Cook 1980) suggests that potential criminals may learn of law changes through the media and will change behavior even with imperfect knowledge of new sanctions. Discussions of the author's with criminal defendants and public defenders indicate that at least some defendants are aware of sanctions. ${ }^{19}$

Imperfect knowledge of law changes may lead to a weakened overall deterrent effect, and also to a modification of the timing in the response to penalty changes. All specifications presented thus far have used the law's effective date as the key independent variable. But this date is often months or even years after the law has been debated in the legislature. New laws are likely to receive the most publicity and have the

\footnotetext{
${ }^{18}$ In order to gain a better understanding of when potential offenders are likely to have learned of add-on gun laws, I collected data from local newspapers about gun legislation. This turns out to be a difficult task. For each of the 30 states that ever passed add-on gun laws, I searched for newspaper article availability for the largest newspaper in the state capital and in the largest city. Although most newspapers have archives going back to the 1990's, because many of the add-on laws were passed earlier, data was only available from six newspapers, representing four states, around the time of the add-ons. For these newspapers, searches were run with various permutations of the terms firearm, gun, add-on, mandatory minimum, law, legislation, in order to determine which period had the greatest news coverage of the law change. There was weak evidence of more publicity around the date of passage, but insufficient power to find statistical significance.

${ }^{19}$ An example of a media source that provides information on gun laws is Don Diva, a hip-hop magazine that has run articles entitled "What are Mandatory Minimums?" and "What Every Gangster Needs to Know."
} 
greatest effect on behavior around the date of legislative introduction or passage (see footnote 18). To test this hypothesis, I collected the dates of legislative bill introduction or passage (the former are difficult to obtain for a number of states, but the latter may be found in state codes or legislative histories) and report these in Table 1.

I replicate the regressions above using the date of bill passage instead of implementation and find a somewhat shifted time structure of the crime response, relative to the previous specifications (Figure 7). The greatest declines in gun robbery rates occur in the first two years following the date of passage of the law, before leveling out. The point estimates using date of passage are very similar to those reported above using the effective date of the law change. This supports the hypothesis above regarding the timing of criminal response corresponding more closely to the date of passage.

Although the law change is not yet effective, there are two mechanisms that could account for an immediate reduction in crime. First, a forward-looking fully rational criminal may wish to change "careers" immediately, since the expected net benefits of crime have been reduced. Second, the information a potential criminal receives about the law change may be imperfect. For example, the potential offender may hear about a law change when it is publicized through the media, and may assume that it is effective immediately. I do not attempt to distinguish these explanations here, and continue to use the timing of the base specification for all other regressions.

\section{B. Impact of Mandatory Minimum Laws}

One of the most significant potential confounds of the deterrence interpretation is the possibility of other policy changes contemporaneous with add-on gun laws. The most 
likely candidate for such a contemporaneous change is a mandatory minimum law. Many of the states that adopted add-on gun laws also adopted another type of law aimed at reducing gun violence, mandatory minimums. These laws provide for a lower bound on sentences for crimes involving the use of a firearm. As discussed previously, since mandatory minimums are often not binding, it makes a deterrence interpretation problematic.

I test for an impact of mandatory minimum laws using the same methodology as used for add-on gun laws. Table 2 presents coefficients on mandatory minimum law dummies in regressions including add-on law dummies as well. None of the coefficients on the mandatory minimum dummies are significant. The same results were found when running specifications including only mandatory minimum dummies, without those for add-on laws. In Figure 8 I report coefficients from the event study specification, relative to the effective date of mandatory minimum laws. While there appears to be a downward trend in per capita gun robberies following introduction of mandatory minimum laws (especially in the specification including state trends) the magnitude is small relative to the standard errors, and the impact is statistically insignificant. Mandatory minimums appear to have at best a weak effect on gun robberies, thus ruling out this policy change as the driver of the main results.

\section{Robustness Checks}

To check the robustness of the finding of a deterrent effect of add-on gun laws, a number of other specifications were tested. I discuss potential confounds and how they were addressed. 


\section{Linear Specification}

In all specifications presented thus far, the log crime rate has been used as the outcome. The choice of log was discussed in part A of Section IV, but there may be reasons why the simple crime rate would be the preferred outcome. If for example, one preferred the assumption that equal changes in crime rates should be treated equally, regardless of initial level of crime, then crime rate is the preferred measure. Figure 9 presents coefficients from the event study methodology where the outcome is per capita gun robberies. The pattern is very similar to that found using log per capita gun robberies as the outcome.

Table 8 presents coefficients from a number of robustness checks. The basic specification in the table is to report the effect of add-on gun laws on log gun robberies

per capita within the first 3 years of the effective date. In the first row of Table 8 , the coefficients from the linear specification are presented (and thus the outcome is gun robberies per capita). While a number of the coefficients are insignificant at the 5\% level, most are significant at the $10 \%$, and they are all negative and of a magnitude that is consistent with the coefficients found using log crime rates.

\section{Restricted comparison group: only states ever passing add-on laws}

Another potential concern is that the comparison group for the basic specification uses all states, regardless of whether they ever passed an add-on gun law. If there is a secular difference in the time series between states adopting add-on laws and those not adopting them (not already captured by controls) this could impact the results. In 
regressions restricted to those states that ever pass an add-on gun law (Table 8, row 2), I find very similar coefficients to those presented in Table 2.

\section{State Level Data}

Since the laws of interest in this study are at the state level, it is useful to compare the results to those obtained using aggregate state-level data sets. State-level data has the advantage of being substantially less noisy than agency data, and incorporates a considerably larger fraction of the U.S. population. However, as noted before, it has the disadvantage of representing a widely varying population. I find that the impact of addon gun laws on gun robbery rates using state level data is similar to that found using agency level data (Table 8, row 3).

\section{Population and Weighting}

Population data provided in the UCR was used both to calculate crime rates and to weight data appropriately, and thus all reported results are sensitive to population data. Several specification checks were performed to ensure that the results are not due to spurious population numbers. They include running the regressions unweighted by population (Table 8, row 4), using number of incidents as the dependant variable (rather than per capita- reported in Table 8 , row 5), and not allowing agency populations to vary over time (Table 8, row 6). All of the specification checks yielded a negative impact of the add-on gun laws on gun robberies, although the first two were statistically insignificant. 


\section{Higher order time trends}

State legislatures may respond not simply to trends in crime, but to an acceleration in crime rates increases, or to short term spikes that are not easily captured using linear trends. Not including higher order time trends in the regressions allows for the possibility that some of the nonlinearity observable in the pre-add-on periods in Figure 3 is due to this phenomenon. I addressed this concern by adding a cubic function of time to the basic regressions (Table 8, row 7), with the central findings unchanged.

\section{Triple Differences}

If sentences of larger magnitude have a greater deterrent effect, one would expect to see a larger drop in gun robberies in those states with a larger add-on prison term. This dimension, add-on sentence term, can be interacted with the previous difference in difference to yield the triple difference specification presented in Equation (4). The addition of a third dimension can be used to address the confound of contemporaneous policy changes as long as one does not expect a correlation between add-on magnitude and contemporaneous policy changes.

One empirical difficulty with estimating the triple difference is that data on the add-on sentence term is quite noisy. A number of states have fairly large ranges for their add-on sentence lengths, and thus the coding of this variable is difficult. ${ }^{20}$ Perhaps due to this fact, the results from the triple difference regressions (Table 9) are largely

\footnotetext{
${ }^{20}$ When states have a range of add-on sentence length I used the minimum add-on term.
} 
insignificant. While insignificant, the coefficients are almost all negative providing weak evidence against the contemporaneous policy change possibility.

\section{E. Lagged Dependant Variables}

As discussed in Section III, part D, crime rates may be a function of their lagged values and thus should be modeled using a lagged dependant variable specification, as in Equation (5). In order to address the violations of OLS assumptions inherent in estimating a model of this kind, I make use of the instrumental variables method described in Arellano and Bond (1991) and Blundell and Bond (1998). I use all lags of at least two years in per capita guns robberies, along with differences of the control variables to instrument for the lagged dependant variable, with the results shown in Table $10 .^{21} \mathrm{I}$ also report tests of the identifying assumptions of the instrumental variables strategy.

The Arrelano-Bond test for autocorrelation in panel data shows strong evidence for rejecting the assumption of no first order autocorrelation $(\mathrm{p}<.002)$, but cannot reject the assumption of no higher order autocorrelation $\left(2^{\text {nd }}\right.$ through $5^{\text {th }}$ order autocorrelation was tested). The Hansen J statistic was calculated for the overidentifying restrictions, and could not reject the hypothesis that the instruments were jointly exogenous. The specification yields an insignificant estimate that there was a $6 \%$ drop in the rate of gun robberies within three years of the add-on gun law effective date, using the preferred specification. Thus it appears that any bias caused by omission of the lagged crime rate is not substantial, and this finding bolsters the main results.

\footnotetext{
${ }^{21}$ In order to use the techniques outlined in the above papers, I aggregated data to the state level.
} 


\section{$\underline{\text { F. Trend Breaks }}$}

As discussed in part E of Section III, a fuller behavioral model of crime might predict a response in crime rates that would not fully be captured by a mean shift in crime rates. Even a rational model where learning is not instantaneous would lead to a change in the crime trend (as seen in the empirical data) rather than a step function. In order to address this possibility, I estimate equation (7), which adds a break in crime time trend relative to the add-on law effective date. I do not find evidence for a significant shift in slope using this specification (Table 8, row 8). This is likely due to the fact that the mean shift captures most of the pre-post add-on shift in crime. However, the addition of higher order terms of relative time, motivated by a more detailed theory of dissemination of information on sanctions to potential criminals could be a better fit to the data.

\section{G. Placebo Laws}

Bertrand et al. (2004) point out that standard errors in difference-in-difference regressions are often misestimated. This problem is particularly apparent in studies like the present one where the independent variable of interest is a dummy for a one-time law change, and therefore has substantial autocorrelation. I address this potential difficulty by adopting both of the remedies suggested in the paper: clustering standard errors, and using placebo laws ${ }^{22}$ to generate standard errors.

All errors reported in the tables are clustered by state; in Table 11, I report standard errors generated by a Monte Carlo simulation. For each iteration of the simulation, a set of placebo laws was generated, by choosing with replacement from the

\footnotetext{
${ }^{22}$ Helland and Tabarrok (2004) provide an excellent example of the importance of using placebo laws. They show that some of the most significant results found by Lott and Mustard in their 1997 paper become insignificant when using standard errors generated by placebo laws.
} 
effective dates for the actual add-on laws. A new effective date (or none) is assigned to each state. A series of regressions are run using the placebo laws, and the point estimates recorded. The simulation is iterated 500 times, and the resulting standard errors reported in square brackets in Table 11.

The specification in this table is slightly different from those discussed previously in two ways. The data used is at the state-month level and the window of time used is symmetric around the add-on law effective date. For example, the two year impact uses data from two years prior to until two years after the add-on effective date.

The results here are consistent with those found previously using agency-level data. There seems to be a substantial deterrent effect of the add-on laws, which increases over the first three years. The coefficients in these regressions are not directly comparable to those from the annual ones, although they do seem to indicate a somewhat larger magnitude of impact of the add-on laws.

Importantly, the coefficients are still significant in a number of the specifications even when using the confidence intervals generated using the placebo laws. The standard errors generated by the simulation are larger than those resulting from asymptotic assumptions, although the clustering already makes a substantial correction to the standard errors. The placebo laws provide a strong test of the validity of the preceding analysis, which appears robust.

\section{Conclusion}


The question of how to best reduce crime is one of perennial importance, made even more salient during periods of budgetary strain. Incarceration is currently by far the most favored method to reduce crime in the United States, and it acts primarily through two channels, incapacitation and deterrence. Disentangling the relative contributions of the two channels is of primary importance in establishing sensible sentencing policies.

In this paper, I use the introduction of add-on gun laws to isolate the deterrent effect of incarceration. Since defendants sentenced under add-on gun laws receive sentences of several years for their underlying crime, any impact on crime within the first several years of an add-on gun law may be interpreted as due solely to its deterrent effect.

I find that this effect on gun robberies is significant, with a per-capita reduction of $5 \%$ within three years of the law's effective date. This reduction in gun robberies does not seem to come at substantial expense from criminals substituting to other types of crime. Non-gun robberies and burglaries display a weaker response to add-on laws, but in the same direction, supporting the notion that add-on gun laws may have positive, not negative spillovers.

While it is difficult completely rule out that passage of add-on gun laws is endogenous, or that contemporaneous policy changes may be responsible for some of the findings, I present substantial evidence addressing these concerns. Numerous alternate specifications are explored to attempt to verify the robustness of the central findings. Contemporary newspaper data suggests that legislative action is often spurred by idiosyncratic crimes. Although triple differences and lagged dependant variable specifications produce insignificant results, they are directionally supportive of the main findings. Tests using various restricted data sets as well as different controls and time 
trends, reinforce the central finding. A Monte Carlo simulation using placebo laws was performed to ensure that the results were not due simply to understating standard errors.

Previous research into deterrence has often been limited to single jurisdictions or unable to make use of natural experiments to establish a causal relationship. This paper should solidify help solidify our evidence for deterrence from incarceration. While the jurisdictions vary, it is useful to compare the magnitude of the estimates found in this paper with others. The $5 \%$ three year decline in this paper is close in magnitude to the 8\% drop found by Kessler and Levitt (1999). Since the magnitude of sentence enhancements in that paper are similar to gun add-ons, this is an encouraging result.

Other papers use sentencing changes that are substantially different from those in this paper, and so a comparison of elasticities is more illuminating. A quick back of the envelope calculation yields an elasticity of approximately -.10 in the current paper. This magnitude is consistent with that found by Lee and McCrary (2009). They bound allowable elasticities consistent with their data and model to have a magnitude no greater than -.13, although their preferred parameter values yield elasticities close to 0 . The largest recent empirical elasticity estimates come from Drago, et al. (2009) using Italian data, where they find a magnitude of -.74 for 7 months. This may be an indication that the substantially lower incarceration rate in Italy makes it difficult to extrapolate to the United States. A back of the envelope calculation using Helland and Tabarrok's (2007) results from examining three strikes induced change yields an elasticity around -.07.

The main finding in this paper is of a robust deterrent effect of incarceration. As the preceding discussion illustrates, the magnitude of the effect found here is consistent with some prior results from individual jurisdictions, although there is a wide range of 
estimates. In looking toward future research and implications for policy, one must recognize that the magnitude of deterrence, and not just its existence, is paramount. 


\section{References}

Arellano, M. and S. Bond. "Some tests of specification for panel data: Monte Carlo evidence and an application to employment equations." The Review of Economic Studies, 1991, 58, pp. 277-97.

Ayres, I. and J.J. Donohue. "Shooting Down the 'More Guns, Less Crime' Hypothesis." Stanford Law Review, 2003, 51(4), pp. 1193-1312.

Baltagi, Badi H. Econometric Analysis of Panel Data. John Wiley \& Sons, New York, NY, 2001.

Bertrand, Marianne, Esther Duflo and Sendhil Mullainathan. "How Much Should We Trust Differences-in-Differences Estimates?” The Quarterly Journal of Economics, 2004, $119(1)$, pp. 249-275.

Beck, Allen J. and Paige Harrison. "Number of sentenced inmates incarcerated under State and Federal jurisdiction per 100,000, 1980-2004." United States Bureau of Justice Statistics, 2005. Available at: http://www.ojp.usdoj.gov/bjs/glance/incrt.htm.

Becker, Gary S. "Crime and Punishment: An Economic Approach." The Journal of Political Economy, March 1968, 76(2), pp. 169-217.

Blundell, R. and S. Bond. "Initial conditions and moment restrictions in dynamic panel data models." Journal of Econometrics, 1998, 87, pp. 115-43.

Britt, Chester L., David J. Bordua, and Gary Kleck. "A Reassessment of the D.C. Gun Law: Some Cautionary Notes on the Use of Interrupted Time Series Design for Policy Impact Assessment.” Law and Society Review, 1996, 30(2), pp. 361-380.

Caselli, Francesco, Gerardo Esquivel, and Fernando Lefort. "Reopening the Convergence Debate: A New Look at Cross-Country Growth Empirics.” Journal of Economic Growth, 1996, Vol, 1.

Chen, M. Keith, and Jessie Shapiro. "Do Harsher Prison Conditions Reduce Recidivism? A Discontinuity-Based Approach.” American Law and Economic Review,2007, 9(1), pp. 1-30.

Cook, Philip J. "Research in Criminal Deterrence: Laying the Groundwork for the Second Decade.” Crime and Justice, Vol. 2, 1980, pp. 211-268.

DiIulio, John and Anne Piehl. "Does Prison Pay? The Stormy National Debate over the Cost-Effectiveness of Imprisonment.” The Brookings Review, Fall 1991, pp. 28-35. 
Donohue, John J. "Guns, Crime, And The Impact Of State Right-to-carry Laws." Fordham Law Review, November 2004, 73(2).

Doob, Anthony M. and Cheryl Webster. "Sentence Severity and Crime: Accepting the Null Hypothesis." Crime and Justice, 2003, Vol. 30, pp. 143-195.

Drago, Francesco, Roberto Galbiati, and Pietro Vertova. "The Deterrent Effects of Prison: Evidence from a Natural Experiment." Journal of Political Economy, 2009, 117 (2), pp. 257-280.

Duggan, Mark. “More Guns, More Crime.” Journal of Political Economy, 2001, 109: $1086-1114$.

Ehrlich, Isaac. "On the Usefulness of Controlling Individuals: An Economic Analysis of Rehabilitation, Incapacitation and Deterrence." The American Economic Review, June 1981, Vol. 71, No. 3, pp. 307-322.

Friedberg, Leora. "Did Unilateral Divorce Raise Divorce Rates? Evidence from Panel Data." American Economics Review, 1998, 88(3).

Helland, Eric and Alexander Tabarrok. "Using Placebo Laws to Test "More Guns, Less Crime"." Advances in Economic Analysis and Policy, 2004, 4(1), article 1, pp. 1-7.

_ . "Does Three Strikes Deter: A Non-Parametric Investigation," Journal of Human Resources, Spring 2007, 42 (2), 309-330.

Hjalmarsson, Randi. "Crime and Expected Punishment: Changes in Perceptions at the Age of Criminal Majority." American Law and Economics Review, 2009, Vol. 11, Issue 1, pp. 209-248.

Jacobson, Louis S., Rober J. LaLonde, and Daniel G. Sullivan. "Earnings Losses of Displaced Workers." The American Economic Review, September 1993, 83(4), pp. 685-709.

Katz, Lawrence, Steven D. Levitt, and Ellen Shustorovich. "Prison Conditions, Capital Punishment, and Deterrence." American Law and Economics Review, 2003, 5(2), pp. 318-343.

Kessler, Daniel P. and Anne Morrison Piehl. "The Role of Discretion in the Criminal Justice System.” Journal of Law, Economics and Organizations, 1998, 14(2), pp. 256-276.

and Steven D. Levitt. "Using Sentence Enhancements to Distinguish between Deterrence and Incapacitation." Journal of Law and Economics, April 1999, 42(1), pp. 343-363. 
Lee, David S. and Justin McCrary. "The Deterrence Effect of Prison: Dynamic Theory and Evidence." Working Paper, July 2009.

Levitt, Steven D. "The Effect of Prison Population Size on Crime Rates: Evidence from Prison Overcrowding Litigation.” The Quarterly Journal of Economics, May 1996, 111(2), pp. 319-351.

. "Using Electoral Cycles in Police Hiring to Estimate the Effect of Police on Crime.” The American Economic Review. June 1997, 87(3), pp. 270-290.

- "Why Do Increased Arrest Rates Appear to Reduce Crime: Deterrence, Incapacitation, or Measurement Error?" Economic Inquiry, 1998a, 36(3), pp. 353372. 1185.

and Thomas J. Miles. "Empirical Study of Criminal Punishment.” In Handbook of Law and Economics, vol. 1, edited by A. Mitchell Polinsky and Steven Shavell. 2007. Amsterdam: North-Holland.

Loftin, Colin and David McDowall. "The Deterrent Effects of the Florida Felony Firearm Law." The Journal of Criminal Law and Criminology, Spring 1984, 75(1), pp. 250259.

Maltz, Michael D. and Joseph Targonski. "Making UCR Data Useful and Accessible." U.S. Department of Justice. Document 205171. April 2004.

Marvell, Thomas B. and Carlisle E. Moody. "The Impact of Enhanced Prison Terms for Felonies Committed with Guns. Criminology, 1995, 33(2), pp. 247-281.

_ . "The Lethal Effects of Three-Strikes Laws." Journal of Legal Studies, January 2001, 30(1), pp. 89-106.

Miles, Thomas and Jens Ludwig. The Silence of the Lambdas: Deterring Incapacitation Research.” Journal of Quantitative Criminology, 2007, 23:287-301.

Nagin, Daniel. "Criminal Deterrence Research at the Outset of the Twenty-First Century," Crime and Justice, 1998, Vol. 23, pp. 1-42.

Pogarsky, Greg, Alex Piquero, and Ray Paternoster. "Modeling Change in Perceptions about Sanction Threats: The Neglected Linkage in Deterrence Theory." Journal of Quantitative Criminology, December 2004, 20(4), pp. 343-369.

Polinsky, A. Mitchell and Steven Shavell. "On the Disutility and Discounting of Imprisonment and the Theory of Deterrence." Journal of Legal Studies, January 1999, 28(1), pp. 1-16. 
Robinson, P. H., \& Darley, J. M. "Does Criminal Law Deter? A Behavioural Science Investigation.” Oxford Journal of Legal Studies, 2004, 24(2), 173-205.

Tonry, Michael. “Mandatory Penalties.” Crime and Justice, 1992, 16, pp. 243-273.

Tunnell, Kenneth D. 1996. "Choosing Crime: Close Your Eyes and Take Your Chances." In Criminal Justice in America: Theory, Practice, and Policy, edited by Barry W. Hancock and Paul M. Sharp. Upper Saddle River, NJ.: Prentice-Hall.

Vernick, Jon S. and Lisa M. Hepburn. "State and Federal Gun Laws: Trends for 197099," in Jens Ludwig, ed., Evaluating Gun Policy: Effects on Crime and Violence, Washington, DC: Brookings Institution Press, 2003.

Waldfogel, Joel. "Criminal Sentences as Endogenous Taxes: Are They 'Just' or 'Efficient'?" Journal of Law and Economics, 1993, Vol. 36, pp. 139-151.

Walmsley, Roy. "World Prison Population List." International Centre for Prison Studies, 2009. Available at http://www.kcl.ac.uk/depsta/law/research/icps/downloads/wppl-8th_41.pdf.

Webster, Cheryl Marie, Anthony N. Doob, and Franklin E. Zimring. "Proposition 8 and Crime Rates in California: The Case of the Disappearing Deterrent." Criminology and Public Policy, 2006, 5(3), pp. 417 - 448.

Wolfers, Justin. "Did Unilateral Divorce Laws Raise Divorce Rates? A Reconciliation and New Results.” American Economic Review, 2006, 96(5), pp. 1802 - 1820.

U.S. Bureau of Justics Statistics. Correctional Populations in the United States. Annual, Washington, DC: U.S. Bureau of Justice Statistics.

- Sourcebook of Criminal Justice Statistics. Annual, Washington, DC: U.S. Bureau of Justice Statistics.

- Weapons Offenses and Offenders. November 1995, Washington, DC: U.S. Bureau of Justice Statistics.

- National Crime Surveys: National Sample, 1973-1983 Codebook. Ann Arbor, MI: Interuniversity Consortium for Political and Social Research [producer and distributor], 1998.

U.S. Dept. of Justice, Federal Bureau of Investigation. Uniform Crime Reporting Program Data: [United States], 1965-2002 [Computer file]. Compiled by the U.S. Dept. of Justice, Federal Bureau of Investigation. ICPSR09028-v5. Ann Arbor, MI: Inter-university Consortium for Political and Social Research [producer and distributor], 2005-09-30. 
Figure 1

\section{Add-on Gun Laws by Date of Enactment}

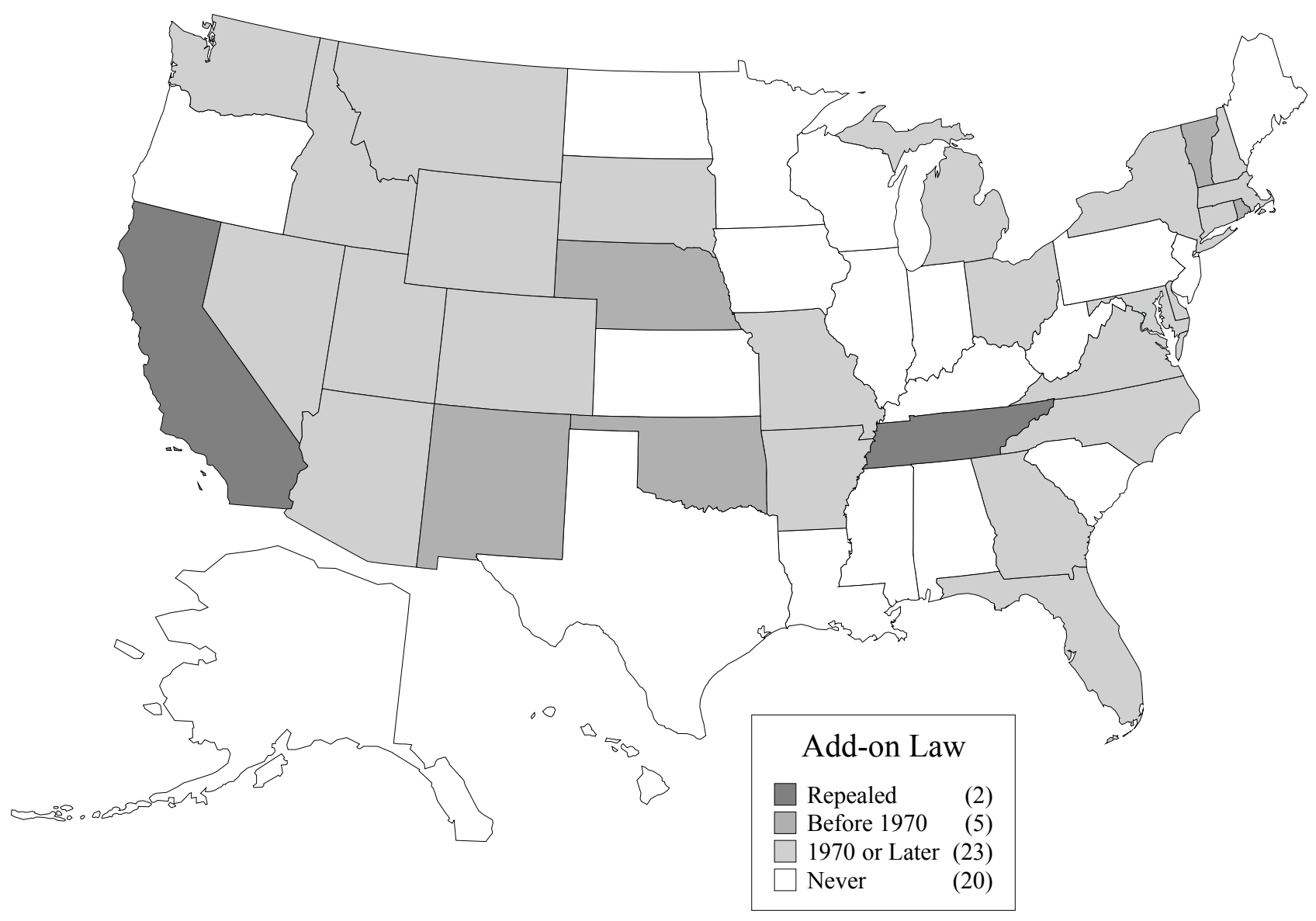




\section{Figure 2}

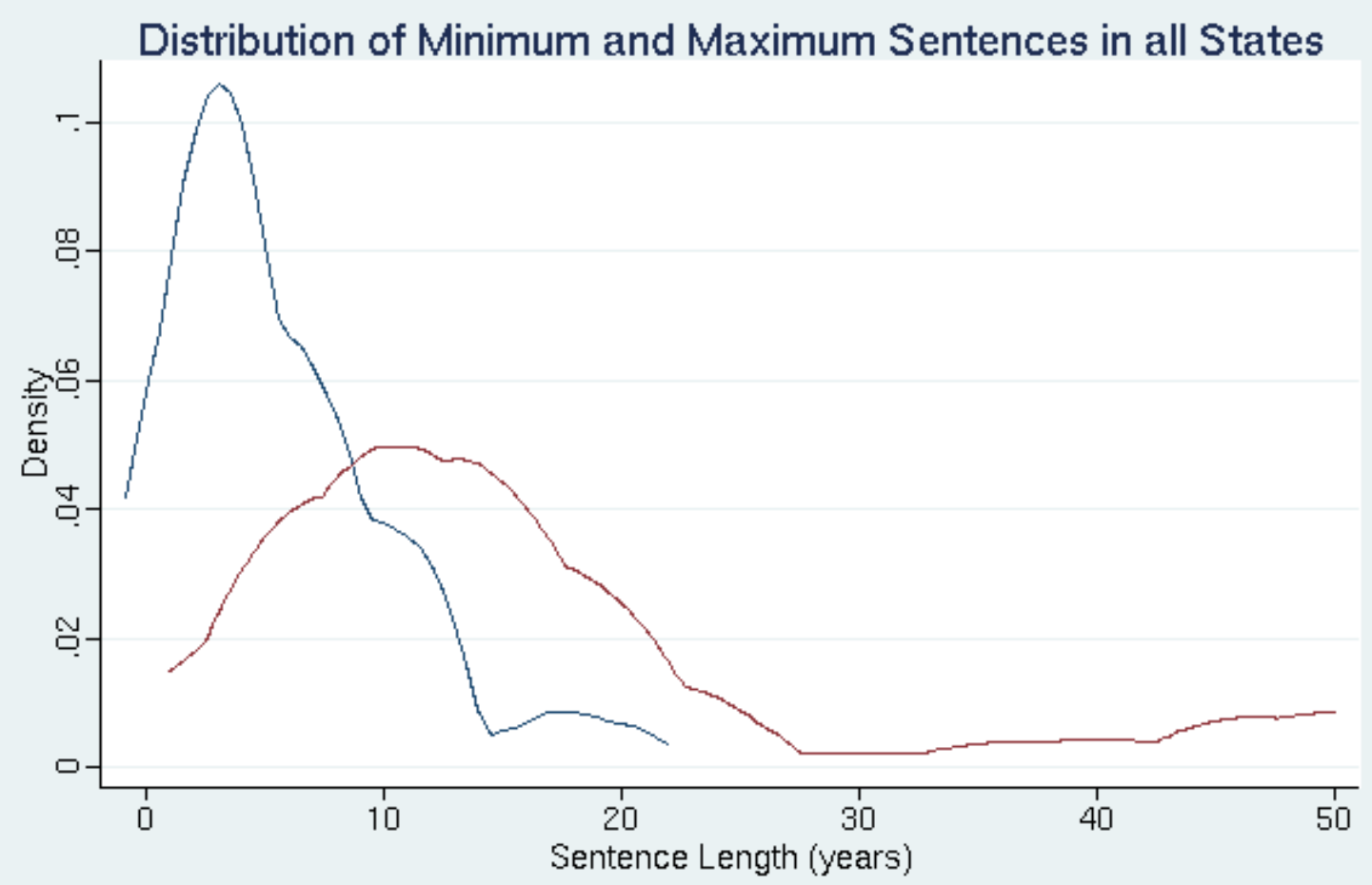

Figure reports two smoothed distributions of robbery sentences. The lower mean distribution is that of the minimum sentence for robbery with a firearm. The higher mean distribution is that of the maximum sentence for robbery with a firearm. Data collected by the author for all U.S. states from state statutes. 


\section{Figure 3}

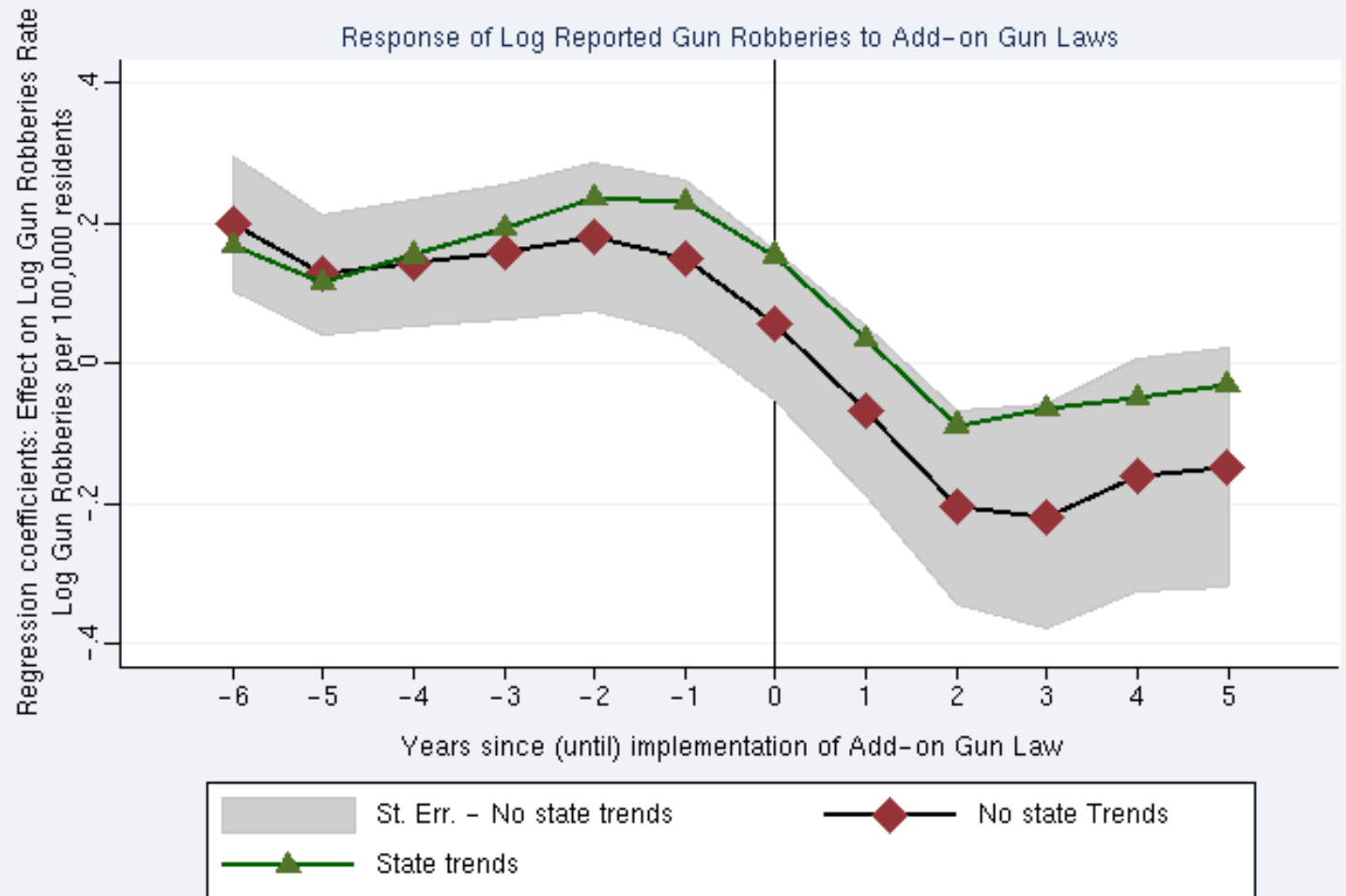

All regressions control for state and year fixed effects. For details, see tables.

\section{Figure 4}

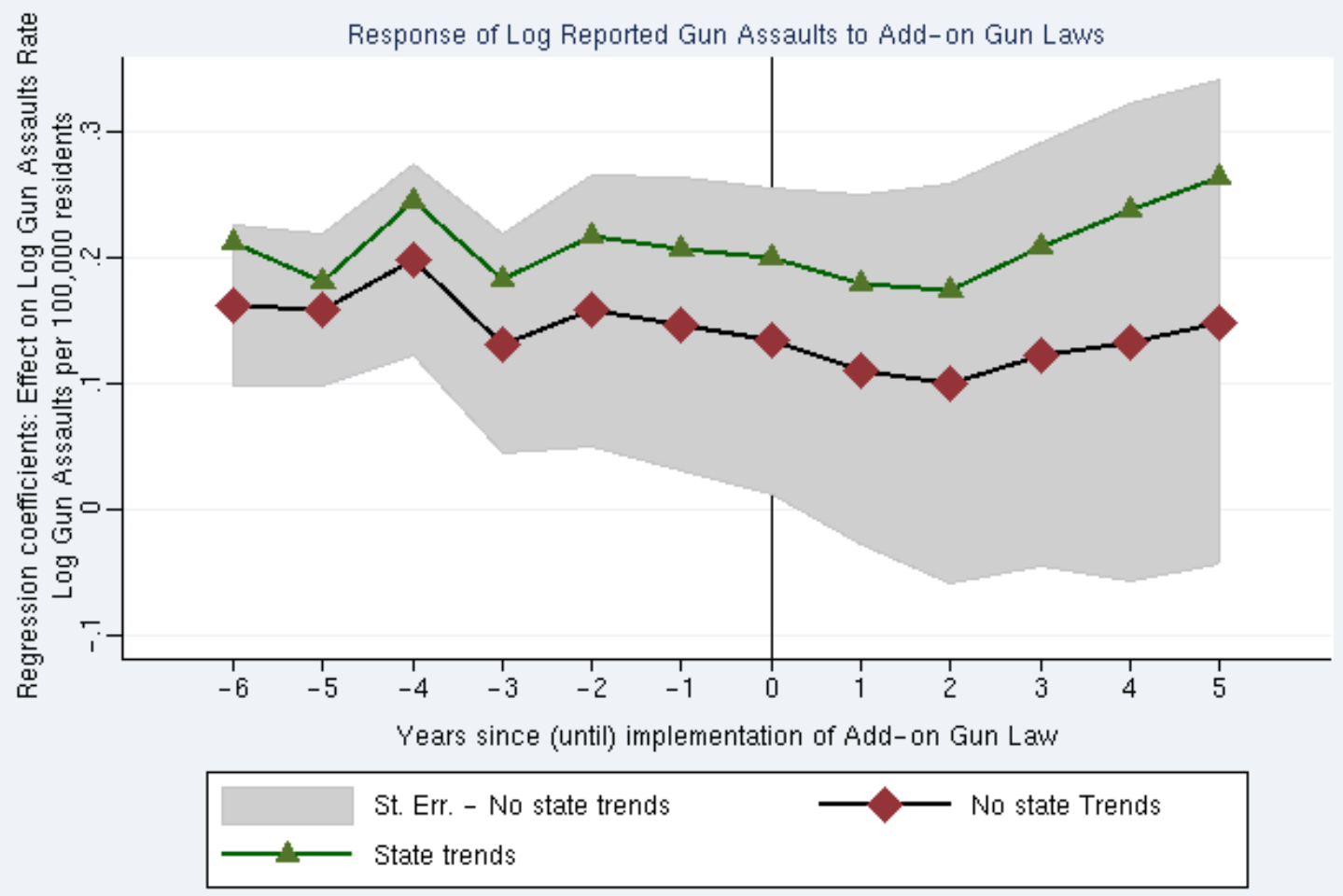

All regressions control for state and year fixed effects. For details, see tables.

Figure 5 


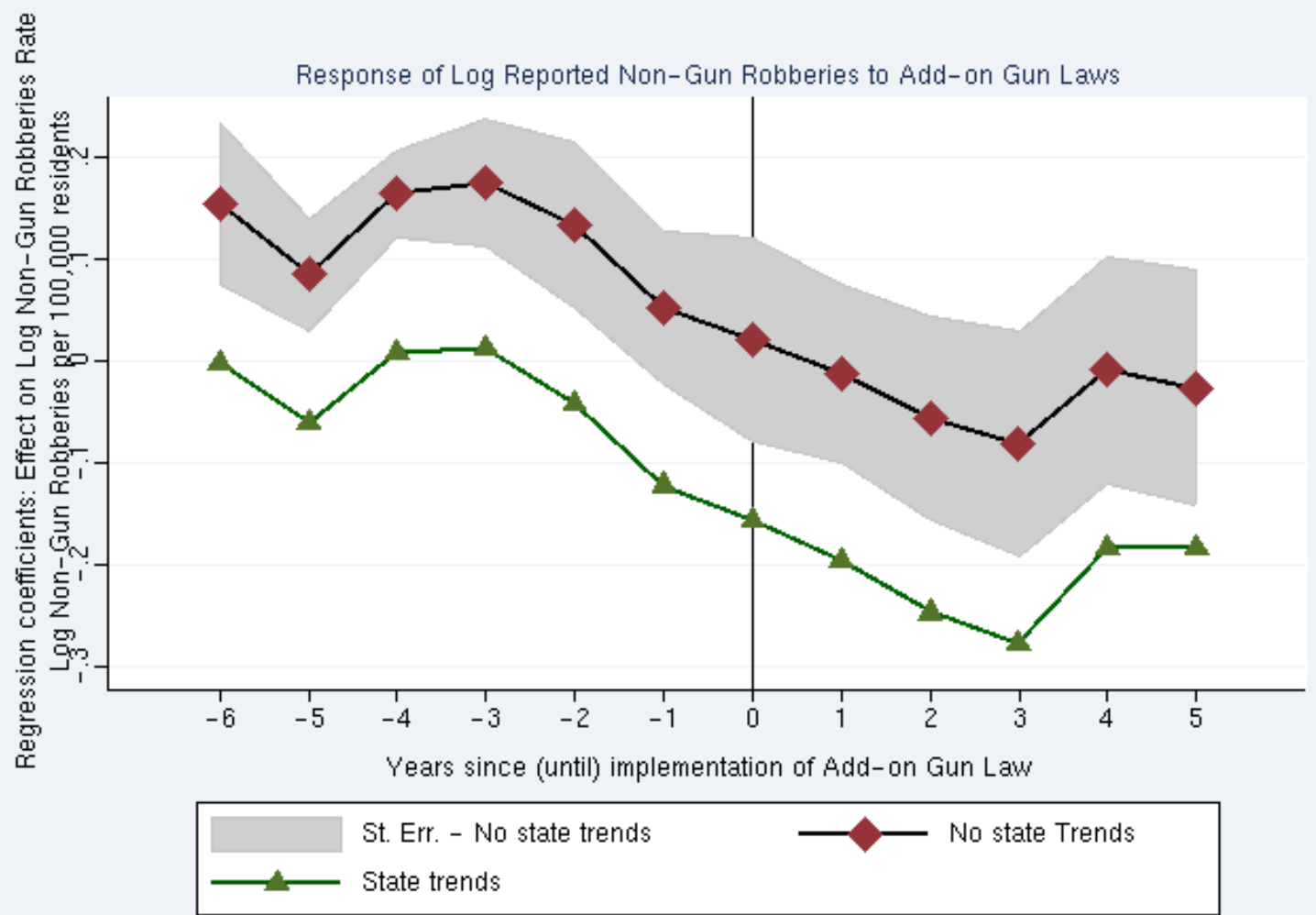

All regressions control for state and year fixed effects. For details, see tables.

\section{Figure 6}

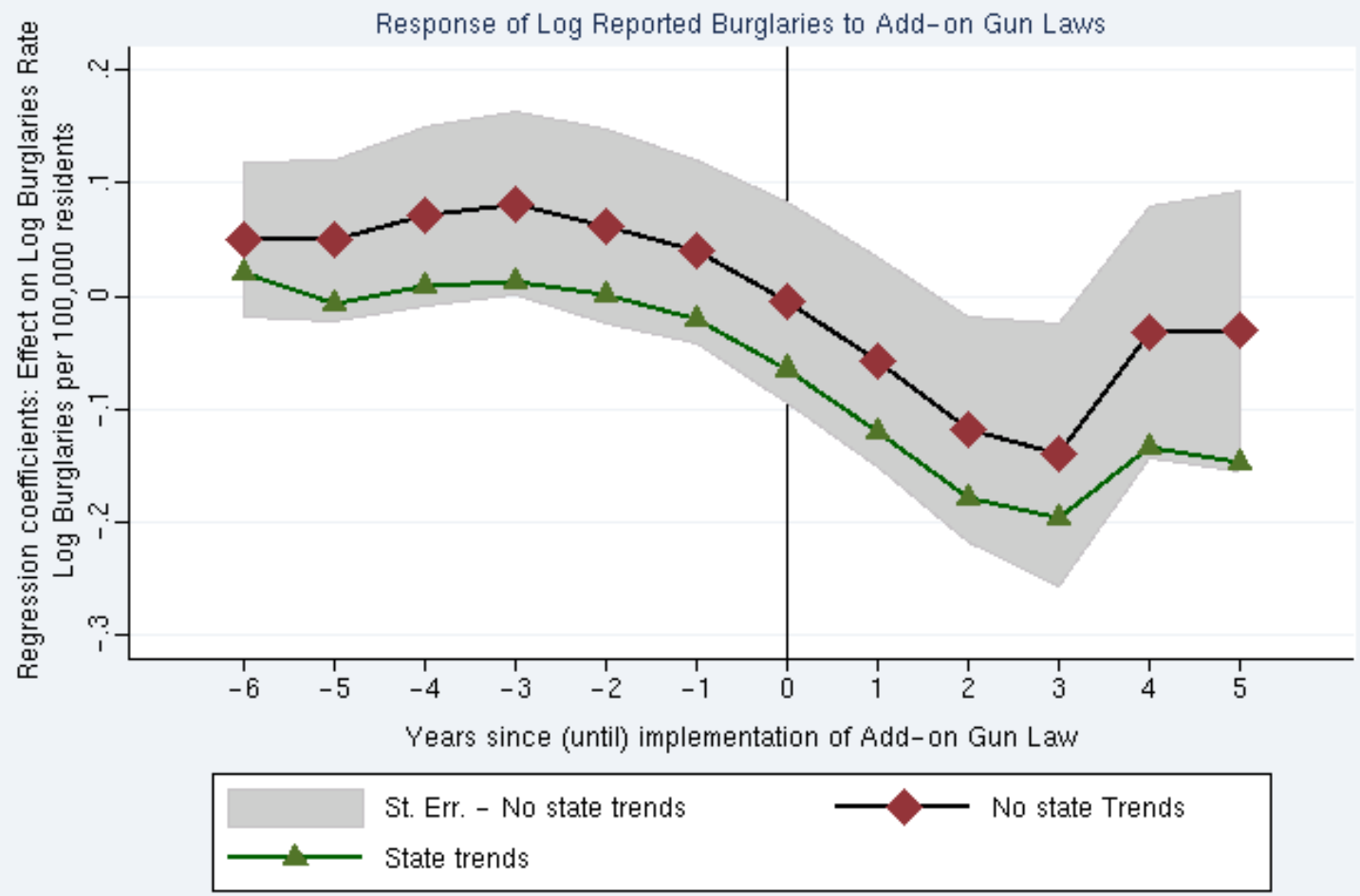

All regressions control for state and year fixed effects. For details, see tables.

\section{Figure 7}




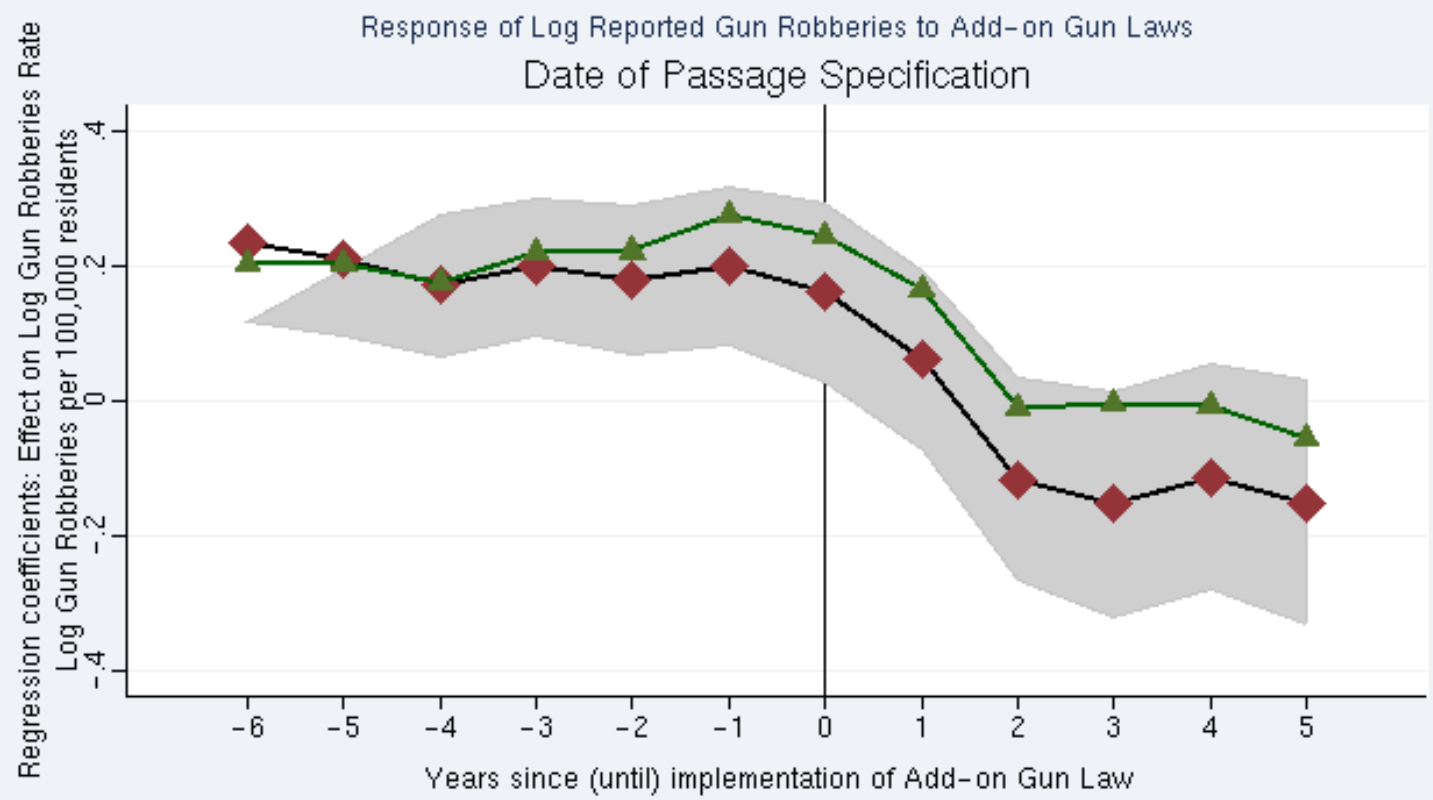

St. Err. - No state trends

No state Trends

State trends

All regressions control for state and year fixed effects. For details, see tables.

Figure 8

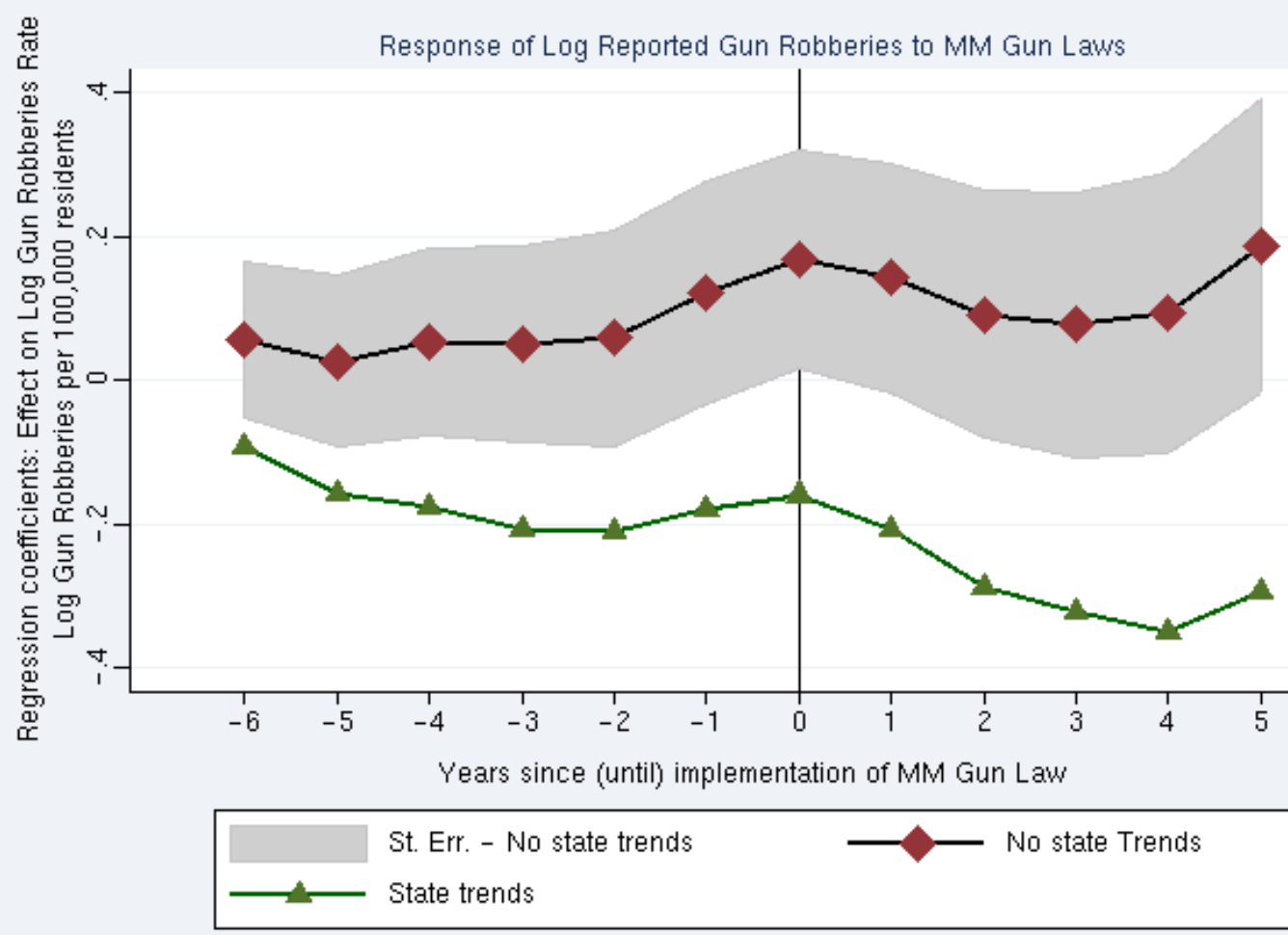

All regressions control for state and year fixed effects. For details, see tables.

\section{Figure 9}




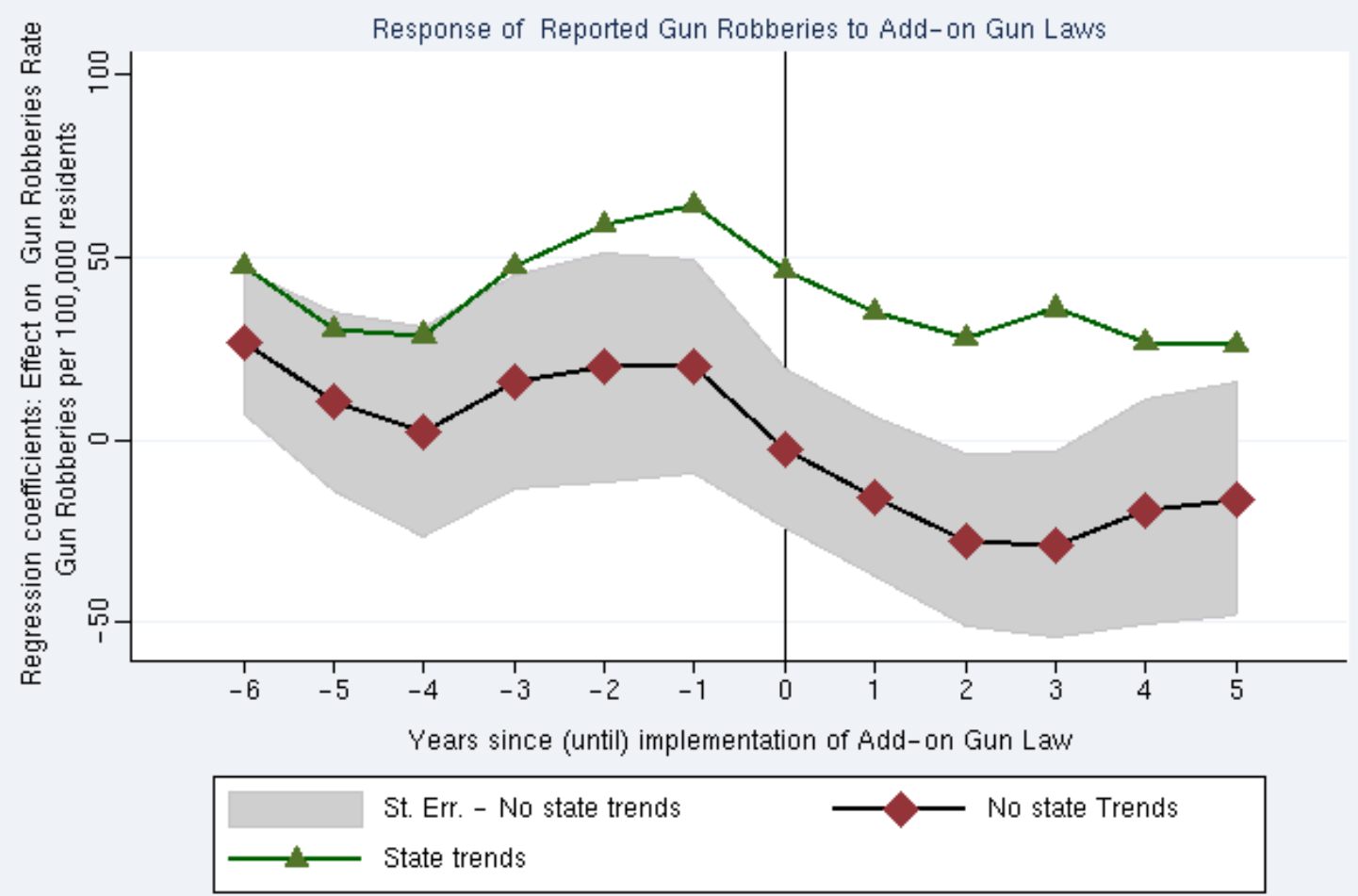

All regressions control for state and year fixed effects. For details, see tables. 


\section{Table 1: Dates of Passage for Add-on Gun Laws}

\begin{tabular}{lrl} 
State & \multicolumn{1}{c}{ Date } & \multicolumn{1}{c}{ Statute (or Bill Number) } \\
\hline Arizona & $5 / 13 / 1974$ & Chapter 144 \\
Arkansas & $2 / 27 / 1981$ & Act 252 \\
California & $11 / 15 / 1976$ & Chapter 2 \\
Colorado & $5 / 10 / 1976$ & House Bill No. 1111 \\
Connecticut & $6 / 8 / 1993$ & House Bill No. 7332 \\
Delaware & $3 / 29 / 1973$ & Chapter 5 \\
Florida & $7 / 3 / 1974$ & Chapter 74-383 \\
Georgia & $4 / 7 / 1976$ & No. 1408 \\
Idaho & $2 / 25 / 1977$ & Chapter 10 \\
Maryland & $3 / 27 / 1972$ & Chapter 4-204 \\
Massachusetts & $8 / 13 / 1974$ & Chap. 830 \\
Michigan & $2 / 11 / 1976$ & Public Act No. 6 \\
Missouri & $6 / 24 / 1976$ & C.C.S.H.B. 1231, 997, 1024, 1116, 1332, and 1346 \\
Montana & $5 / 13 / 1977$ & Chapter 584 95-2206.17 \\
Nevada & $5 / 3 / 1973$ & Assembly Bill No. 234 \\
New Hampshire & $7 / 5 / 1977$ & Chapter 403 \\
New York & $9 / 17 / 1996$ & Chapter 650 \\
North Carolina & $3 / 26 / 1994$ & Chapter 22 \\
Ohio & $10 / 5 / 1982$ & Amended Substitute Senate Bill No. 199 \\
South Dakota & $3 / 14 / 1985$ & Chapter 192 \\
Tennessee & $3 / 29 / 1976$ & Chapter No. 768 \\
Utah & $2 / 11 / 1976$ & Chapter 9 \\
Virginia & $3 / 24 / 1975$ & Chapter 628 \\
Washington & $3 / 27 / 1984$ & Chapter 209 \\
Wyoming & $3 / 8 / 1979$ & Chapter 158 \\
\hline & & \\
& & \\
\hline
\end{tabular}


Table 2: Impact of Add-on Gun Laws on Log Reported Gun Robberies Per Capita Panel A: One year Impact

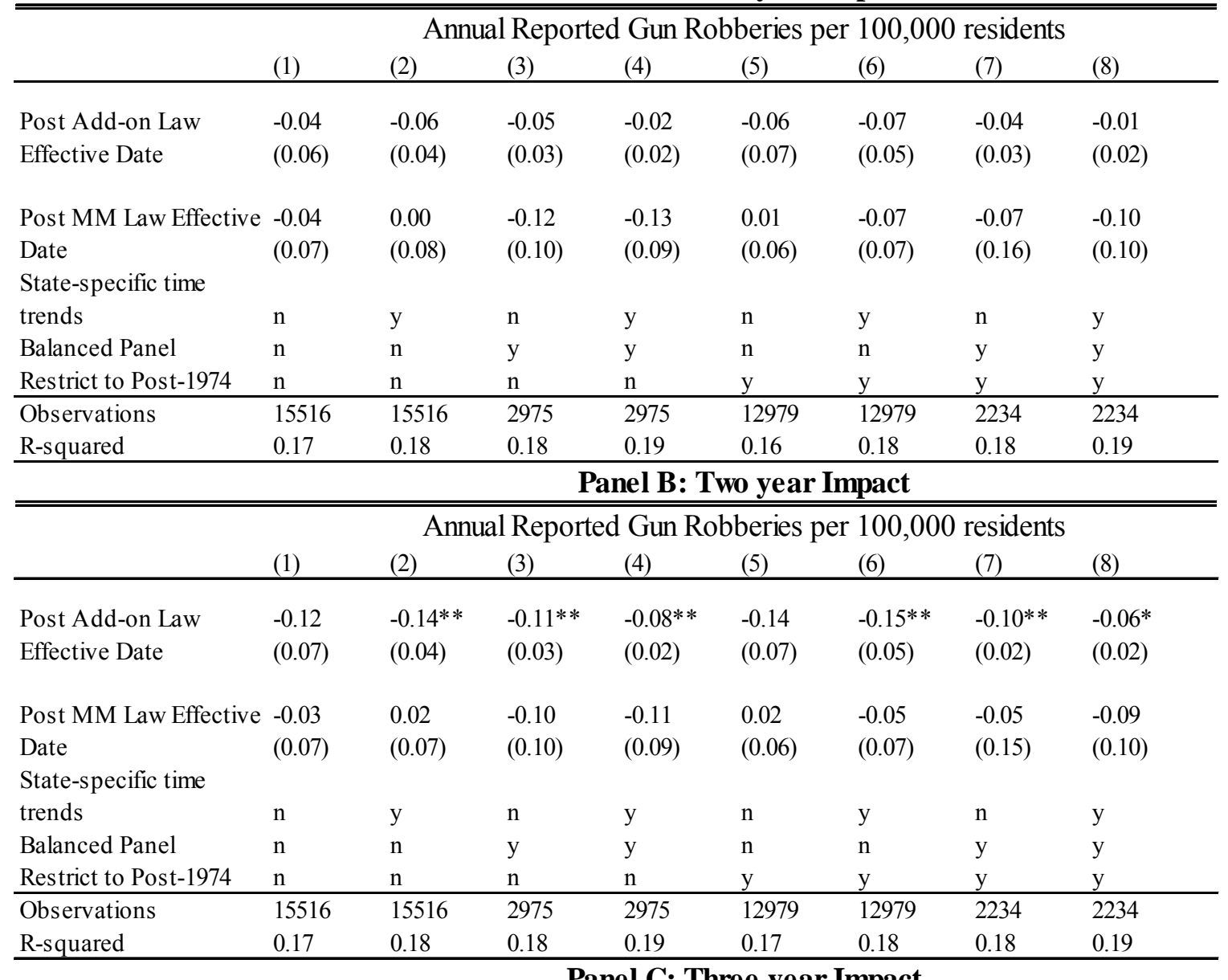

Panel C: Three year Impact

\begin{tabular}{llllllllll}
\hline \hline & \multicolumn{7}{c}{ Annual Reported Gun Robberies per 100,000 residents } \\
& $(1)$ & $(2)$ & $(3)$ & $(4)$ & $(5)$ & $(6)$ & $(7)$ & $(8)$ \\
\hline Post Add-on Law & -0.14 & $-0.17^{* *}$ & $-0.13^{* *}$ & $-0.09^{* *}$ & -0.17 & $-0.18^{* *}$ & $-0.11^{* *}$ & $-0.05^{*}$ \\
Effective Date & $(0.08)$ & $(0.05)$ & $(0.04)$ & $(0.02)$ & $(0.09)$ & $(0.06)$ & $(0.03)$ & $(0.02)$ \\
& & & & & & & & \\
Post MM Law Effective & -0.02 & 0.04 & -0.10 & -0.10 & 0.04 & -0.04 & -0.04 & -0.10 \\
$\begin{array}{l}\text { Date } \\
\text { State-specific time }\end{array}$ & $(0.07)$ & $(0.07)$ & $(0.10)$ & $(0.09)$ & $(0.06)$ & $(0.06)$ & $(0.15)$ & $(0.10)$ \\
trends & $\mathrm{n}$ & $\mathrm{y}$ & $\mathrm{n}$ & $\mathrm{y}$ & $\mathrm{n}$ & $\mathrm{y}$ & $\mathrm{n}$ & $\mathrm{y}$ \\
Balanced Panel & $\mathrm{n}$ & $\mathrm{n}$ & $\mathrm{y}$ & $\mathrm{y}$ & $\mathrm{n}$ & $\mathrm{n}$ & $\mathrm{y}$ & $\mathrm{y}$ \\
Restrict to Post-1974 & $\mathrm{n}$ & $\mathrm{n}$ & $\mathrm{n}$ & $\mathrm{n}$ & $\mathrm{y}$ & $\mathrm{y}$ & $\mathrm{y}$ & $\mathrm{y}$ \\
\hline Observations & 15516 & 15516 & 2975 & 2975 & 12979 & 12979 & 2234 & 2234 \\
R-squared & 0.17 & 0.18 & 0.18 & 0.19 & 0.17 & 0.18 & 0.18 & 0.19 \\
\hline
\end{tabular}

* significant at $5 \% ; *$ significant at $1 \%$

Note - The data consists of a gency-year level observations. Standard errors reported in parentheses a re clustered at the state level to allow for intra-state correlation in error structure. State and year effects a re included in all specifications. Controls include poverty rate, unemployment rate, racialcomposition, age composition, lagged police population share, and lagged imprisoned population share. 


\section{Table 3: Impact of Add-on Gun Laws on Reported Gun Robberies Per Capita}

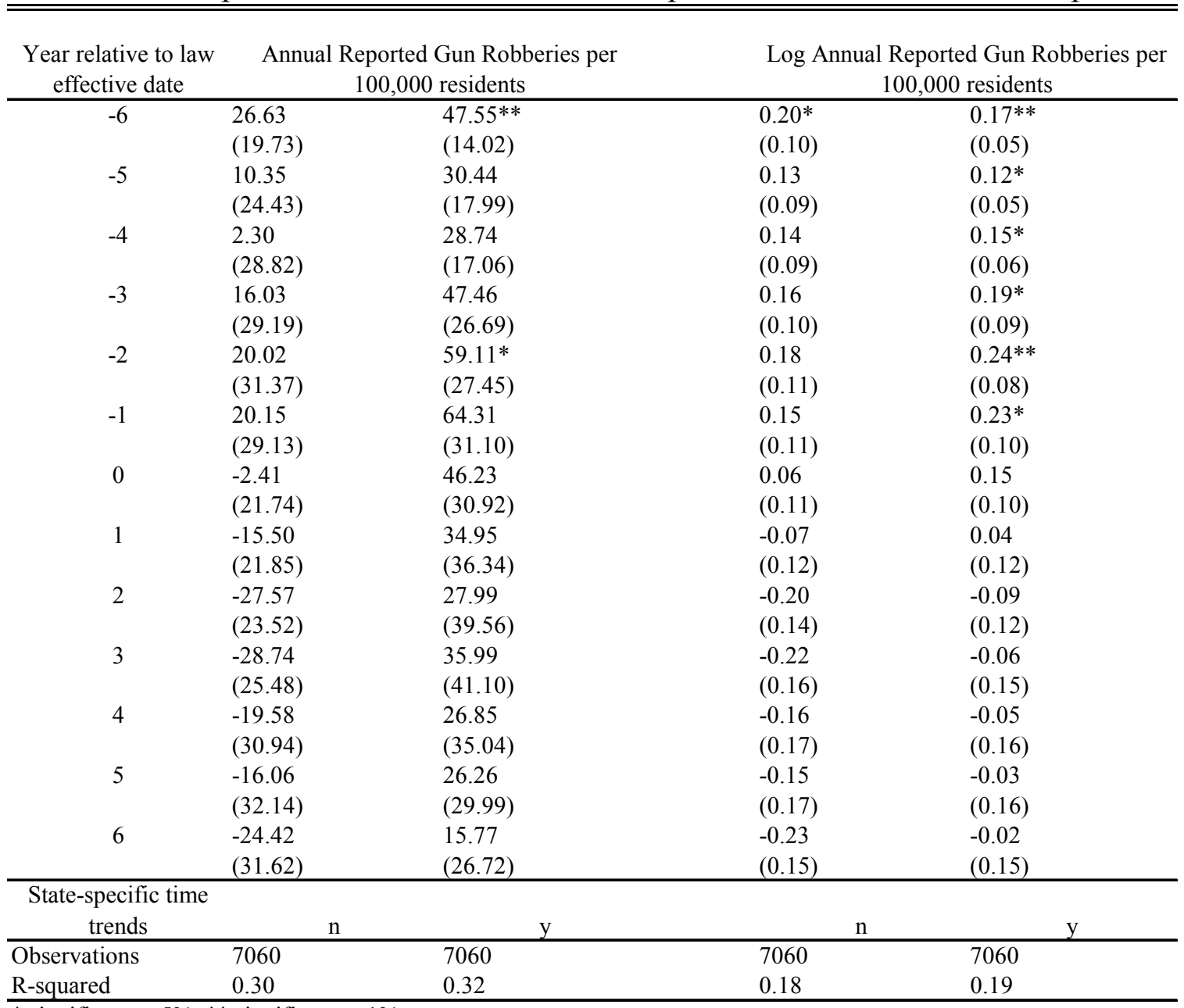

* significant at $5 \%$; ** significant at $1 \%$

Note - The data consists of agency-year level observations. Standard errors reported in parentheses are clustered at the state level to allow for intra-state correlation in error structure. State and year effects are included in all specifications. Controls include mandatory minimum law dummy, poverty rate, unemployment rate, racial composition, age composition, lagged police population share, and lagged imprisoned population share. 
Table 4: Impact of Add-on Gun Laws on Log Reported Gun Assaults Per Capita

\begin{tabular}{llllllllll}
\hline \hline & \multicolumn{7}{c}{ Annual Reported Gun Assaults per 100,000 residents } \\
& $(1)$ & $(2)$ & $(3)$ & $(4)$ & $(5)$ & $(6)$ & $(7)$ & $(8)$ \\
\hline $\begin{array}{l}\text { Within one year post add- } \\
\text { on law effective date }\end{array}$ & 0.01 & -0.02 & -0.01 & 0.01 & 0.02 & -0.04 & -0.01 & 0.03 \\
& $(0.03)$ & $(0.03)$ & $(0.02)$ & $(0.02)$ & $(0.03)$ & $(0.03)$ & $(0.02)$ & $(0.02)$ \\
Within two years post & 0.00 & -0.03 & -0.04 & -0.01 & 0.01 & -0.05 & -0.03 & -0.00 \\
add-on law effective date & $(0.04)$ & $(0.04)$ & $(0.02)$ & $(0.02)$ & $(0.04)$ & $(0.04)$ & $(0.02)$ & $(0.01)$ \\
& & & & & & & & -0.01 \\
Within three years post & -0.00 & -0.03 & -0.04 & -0.01 & 0.01 & -0.05 & -0.04 & -0.01 \\
add-on law effective date & $(0.05)$ & $(0.04)$ & $(0.03)$ & $(0.02)$ & $(0.05)$ & $(0.04)$ & $(0.02)$ & $(0.02)$ \\
& & & & & & & & \\
State-specific time trends & $\mathrm{n}$ & $\mathrm{y}$ & $\mathrm{n}$ & $\mathrm{y}$ & $\mathrm{n}$ & $\mathrm{y}$ & $\mathrm{n}$ & $\mathrm{y}$ \\
Balanced Panel & $\mathrm{n}$ & $\mathrm{n}$ & $\mathrm{y}$ & $\mathrm{y}$ & $\mathrm{n}$ & $\mathrm{n}$ & $\mathrm{y}$ & $\mathrm{y}$ \\
Restrict to Post-1974 & $\mathrm{n}$ & $\mathrm{n}$ & $\mathrm{n}$ & $\mathrm{n}$ & $\mathrm{y}$ & $\mathrm{y}$ & $\mathrm{y}$ & $\mathrm{y}$ \\
\hline Observations & 15486 & 15486 & 2964 & 2964 & 12954 & 12954 & 2223 & 2223 \\
R-squared & 0.33 & 0.34 & 0.37 & 0.37 & 0.32 & 0.33 & 0.39 & 0.40 \\
\hline
\end{tabular}

* significant at $5 \% ; * *$ significant at $1 \%$

Note - The data consists of agency-year level observations. Standard errors reported in parentheses are clustered at the state level to allow for intra-state correlation in error structure. State and year effects are included in all specifications. Controls include manda tory minimum law dummy, poverty rate, unemployment rate, racial composition, age composition, lagged police population share, and lagged imprisoned population share.

Table 5: Impact of Add-on Gun Laws on Log Reported Non-Gun Robberies Per Capita

\begin{tabular}{llllllllll}
\hline \hline & \multicolumn{7}{c}{ Annual Reported Non-Gun Robberies per 100,000 residents } \\
& $(1)$ & $(2)$ & $(3)$ & $(4)$ & $(5)$ & $(6)$ & $(7)$ & $(8)$ \\
\hline Within one year post add- & 0.01 & -0.04 & 0.02 & 0.00 & -0.01 & -0.02 & -0.01 & 0.01 \\
on law effective date & $(0.04)$ & $(0.02)$ & $(0.03)$ & $(0.02)$ & $(0.03)$ & $(0.02)$ & $(0.02)$ & $(0.02)$ \\
& & & & & & & & \\
Within two years post & -0.01 & $-0.06^{*}$ & -0.01 & -0.01 & -0.04 & $-0.05^{*}$ & $-0.04^{* *}$ & -0.02 \\
add-on law effective date & $(0.04)$ & $(0.03)$ & $(0.03)$ & $(0.02)$ & $(0.03)$ & $(0.02)$ & $(0.01)$ & $(0.01)$ \\
Within three years post & -0.03 & $-0.09^{*}$ & -0.03 & $-0.04^{*}$ & -0.06 & $-0.06^{*}$ & $-0.06^{* *}$ & -0.03 \\
add-on law effective date & $(0.04)$ & $(0.04)$ & $(0.03)$ & $(0.02)$ & $(0.04)$ & $(0.02)$ & $(0.01)$ & $(0.02)$ \\
& & & & & & & & \\
State-specific time trends & $\mathrm{n}$ & $\mathrm{y}$ & $\mathrm{n}$ & $\mathrm{y}$ & $\mathrm{n}$ & $\mathrm{y}$ & $\mathrm{n}$ & $\mathrm{y}$ \\
Balanced Panel & $\mathrm{n}$ & $\mathrm{n}$ & $\mathrm{y}$ & $\mathrm{y}$ & $\mathrm{n}$ & $\mathrm{n}$ & $\mathrm{y}$ & $\mathrm{y}$ \\
Restrict to Post-1974 & $\mathrm{n}$ & $\mathrm{n}$ & $\mathrm{n}$ & $\mathrm{n}$ & $\mathrm{y}$ & $\mathrm{y}$ & $\mathrm{y}$ & $\mathrm{y}$ \\
\hline Observations & 15294 & 15294 & 2911 & 2911 & 12866 & 12866 & 2209 & 2209 \\
R-squared & 0.20 & 0.21 & 0.25 & 0.26 & 0.18 & 0.18 & 0.23 & 0.23 \\
\hline
\end{tabular}

* significant at $5 \% ; * *$ significant at $1 \%$

Note - The data consists of agency-year level observations. Standard errors reported in parentheses are clustered at the state level to allow for intra-state correlation in error structure. State and year effects are included in all specifications. Controls include manda tory minimum law dummy, poverty rate, unemployment rate, racial composition, age composition, lagged police population share, and lagged imprisoned population share. 
Table 6: Impact of Add-on Gun Laws on Log Reported Total Robberies Per

\begin{tabular}{lllllllll}
\hline \hline & \multicolumn{7}{c}{ Annual Reported Total Robberies per 100,000 residents } \\
& $(1)$ & $(2)$ & $(3)$ & $(4)$ & $(5)$ & $(6)$ & $(7)$ & $(8)$ \\
\hline Within one year post add- & -0.01 & -0.03 & -0.01 & 0.01 & -0.02 & -0.03 & -0.01 & 0.01 \\
on law effective date & $(0.03)$ & $(0.02)$ & $(0.02)$ & $(0.01)$ & $(0.03)$ & $(0.02)$ & $(0.02)$ & $(0.01)$ \\
& & & & & & & & \\
Within two years post & -0.05 & $-0.08^{* *}$ & $-0.06^{* *}$ & $-0.04^{* *}$ & -0.06 & $-0.08^{* *}$ & $-0.05^{* *}$ & -0.02 \\
add-on law effective date & $(0.04)$ & $(0.02)$ & $(0.02)$ & $(0.01)$ & $(0.04)$ & $(0.02)$ & $(0.01)$ & $(0.01)$ \\
& & & & & & & & \\
Within three years post & -0.07 & $-0.10^{* *}$ & $-0.08^{* *}$ & $-0.06^{* *}$ & -0.08 & $-0.09^{* *}$ & $-0.06^{* *}$ & -0.03 \\
add-on law effective date & $(0.04)$ & $(0.03)$ & $(0.03)$ & $(0.02)$ & $(0.04)$ & $(0.03)$ & $(0.02)$ & $(0.02)$ \\
& & & & & & & & \\
State-specific time trends & $\mathrm{n}$ & $\mathrm{y}$ & $\mathrm{n}$ & $\mathrm{y}$ & $\mathrm{n}$ & $\mathrm{y}$ & $\mathrm{n}$ & $\mathrm{y}$ \\
Balanced Panel & $\mathrm{n}$ & $\mathrm{n}$ & $\mathrm{y}$ & $\mathrm{y}$ & $\mathrm{n}$ & $\mathrm{n}$ & $\mathrm{y}$ & $\mathrm{y}$ \\
Restrict to Post-1974 & $\mathrm{n}$ & $\mathrm{n}$ & $\mathrm{n}$ & $\mathrm{n}$ & $\mathrm{y}$ & $\mathrm{y}$ & $\mathrm{y}$ & $\mathrm{y}$ \\
\hline Observations & 15516 & 15516 & 2975 & 2975 & 12979 & 12979 & 2234 & 2234 \\
R-squared & 0.16 & 0.17 & 0.19 & 0.19 & 0.16 & 0.17 & 0.20 & 0.20 \\
\hline
\end{tabular}

* significant at $5 \% ; *$ significant at $1 \%$

Note - The data consists of agency-year level observations. Standard errors reported in parentheses are clustered at the state level to allow for intra-state correlation in error structure. State and year effects are included in all specifications. Controls include manda tory minimum law dummy, poverty rate, unemployment rate, racial composition, age composition, lagged police population share, and lagged imprisoned population share.

\section{Table 7: Impact of Add-on Gun Laws on Log Reported Total Burglaries Per}

\begin{tabular}{llllllllll}
\hline & \multicolumn{7}{c}{ Annual Reported Burglaries per 100,000 residents } \\
& $(1)$ & $(2)$ & $(3)$ & $(4)$ & $(5)$ & $(6)$ & $(7)$ & $(8)$ \\
\hline Within one year post add- & -0.05 & -0.03 & -0.02 & -0.01 & -0.05 & -0.02 & -0.02 & -0.02 \\
on law effective date & $(0.04)$ & $(0.02)$ & $(0.02)$ & $(0.01)$ & $(0.04)$ & $(0.02)$ & $(0.01)$ & $(0.01)$ \\
& -0.08 & -0.06 & -0.04 & $-0.03^{* *}$ & -0.09 & -0.05 & $-0.04^{* *}$ & $-0.03^{*}$ \\
Within two years post & & & & & & & & \\
add-on law effective date & $(0.05)$ & $(0.03)$ & $(0.02)$ & $(0.01)$ & $(0.05)$ & $(0.03)$ & $(0.01)$ & $(0.01)$ \\
Within three years post & -0.11 & -0.08 & $-0.05^{*}$ & $-0.04^{* *}$ & -0.12 & -0.07 & $-0.06^{* *}$ & $-0.05^{* *}$ \\
add-on law effective date & $(0.06)$ & $(0.05)$ & $(0.02)$ & $(0.01)$ & $(0.06)$ & $(0.04)$ & $(0.02)$ & $(0.01)$ \\
& & & & & & & & \\
State-specific time trends & $\mathrm{n}$ & $\mathrm{y}$ & $\mathrm{n}$ & $\mathrm{y}$ & $\mathrm{n}$ & $\mathrm{y}$ & $\mathrm{n}$ & $\mathrm{y}$ \\
Balanced Panel & $\mathrm{n}$ & $\mathrm{n}$ & $\mathrm{y}$ & $\mathrm{y}$ & $\mathrm{n}$ & $\mathrm{n}$ & $\mathrm{y}$ & $\mathrm{y}$ \\
Restrict to Post-1974 & $\mathrm{n}$ & $\mathrm{n}$ & $\mathrm{n}$ & $\mathrm{n}$ & $\mathrm{y}$ & $\mathrm{y}$ & $\mathrm{y}$ & $\mathrm{y}$ \\
\hline Observations & 15517 & 15517 & 2975 & 2975 & 12980 & 12980 & 2234 & 2234 \\
R-squared & 0.28 & 0.31 & 0.40 & 0.40 & 0.32 & 0.35 & 0.45 & 0.45 \\
\hline * significant at 5\%;* & & & & & & &
\end{tabular}

* significant at $5 \% ; * *$ significant at $1 \%$

Note - The data consists of agency-year level observations. Standard errors reported in parentheses a re clustered at the state level to allow for intra-state correlation in error structure. State and year effects are included in all specifications. Controls include manda tory minimum law dummy, poverty rate, unemployment rate, racial composition, age composition, lagged police population share, and lagged imprisoned population share. 
Table 8: Addressing Confounds

\begin{tabular}{|c|c|c|c|c|c|c|c|c|c|}
\hline & & & & Var & us outcc & hes - se & notes & & \\
\hline & & $(1)$ & (2) & (3) & (4) & $(5)$ & $(6)$ & (7) & $(8)$ \\
\hline (1) & $\begin{array}{l}\text { Outcome is gun robberies } \\
\text { per capita (not log) }\end{array}$ & $\begin{array}{l}-0.71 \\
(12.08)\end{array}$ & $\begin{array}{l}-15.39 \\
(10.99)\end{array}$ & $\begin{array}{l}-20.32 \\
(11.38)\end{array}$ & $\begin{array}{l}-17.28^{*} \\
(7.81)\end{array}$ & $\begin{array}{l}-3.92 \\
(10.51)\end{array}$ & $\begin{array}{l}-17.35 \\
(12.34)\end{array}$ & $\begin{array}{l}-16.90 \\
(9.43)\end{array}$ & $\begin{array}{l}-11.52 \\
(6.40)\end{array}$ \\
\hline (2) & $\begin{array}{l}\text { Only states ever passing } \\
\text { add-on laws }\end{array}$ & $\begin{array}{l}-0.03 \\
(0.07)\end{array}$ & $\begin{array}{l}-0.13^{* *} \\
(0.04)\end{array}$ & $\begin{array}{l}-0.11^{*} \\
(0.04)\end{array}$ & $\begin{array}{l}-0.10^{* *} \\
(0.02)\end{array}$ & $\begin{array}{l}-0.05 \\
(0.06)\end{array}$ & $\begin{array}{l}-0.12^{*} \\
(0.05)\end{array}$ & $\begin{array}{l}-0.10^{*} \\
(0.03)\end{array}$ & $\begin{array}{l}-0.06^{*} \\
(0.02)\end{array}$ \\
\hline (3) & State Level Data & $\begin{array}{l}-0.15 \\
(0.10)\end{array}$ & $\begin{array}{l}-0.20 * * \\
(0.06)\end{array}$ & $\begin{array}{l}-0.15^{* *} \\
(0.04)\end{array}$ & $\begin{array}{l}-0.09 * \\
(0.03)\end{array}$ & $\begin{array}{l}-0.16 \\
(0.11)\end{array}$ & $\begin{array}{l}-0.21 * * \\
(0.06)\end{array}$ & $\begin{array}{l}-0.14 * * \\
(0.04)\end{array}$ & $\begin{array}{l}-0.08 \\
(0.04)\end{array}$ \\
\hline (4) & Unweighted & $\begin{array}{l}-0.09 \\
(0.07)\end{array}$ & $\begin{array}{l}-0.15 * * \\
(0.06)\end{array}$ & $\begin{array}{l}-0.12^{*} \\
(0.05)\end{array}$ & $\begin{array}{l}-0.11 * \\
(0.04)\end{array}$ & $\begin{array}{l}-0.08 \\
(0.07)\end{array}$ & $\begin{array}{l}-0.13^{*} \\
(0.05)\end{array}$ & $\begin{array}{l}-0.11^{*} \\
(0.05)\end{array}$ & $\begin{array}{l}-0.06 \\
(0.03)\end{array}$ \\
\hline (5) & $\begin{array}{l}\text { Reported crimes (not per } \\
\text { capita) }\end{array}$ & $\begin{array}{l}-0.13 \\
(0.09)\end{array}$ & $\begin{array}{l}-0.17 * * \\
(0.06)\end{array}$ & $\begin{array}{l}-0.14^{* *} \\
(0.04)\end{array}$ & $\begin{array}{l}-0.08 * * \\
(0.03)\end{array}$ & $\begin{array}{l}-0.17 \\
(0.10)\end{array}$ & $\begin{array}{l}-0.17 * * \\
(0.06)\end{array}$ & $\begin{array}{l}-0.12 * * \\
(0.03)\end{array}$ & $\begin{array}{l}-0.04 \\
(0.03)\end{array}$ \\
\hline (6) & Initial Populations & $\begin{array}{l}-0.18^{*} \\
(0.07)\end{array}$ & $\begin{array}{l}-0.17 * * \\
(0.05)\end{array}$ & $\begin{array}{l}-0.14^{* *} \\
(0.04)\end{array}$ & $\begin{array}{l}-0.10^{* *} \\
(0.03)\end{array}$ & $\begin{array}{l}-0.20^{*} \\
(0.08)\end{array}$ & $\begin{array}{l}-0.18 * * \\
(0.06)\end{array}$ & $\begin{array}{l}-0.13 * * \\
(0.03)\end{array}$ & $\begin{array}{l}-0.07^{*} \\
(0.03)\end{array}$ \\
\hline (7) & Polynomial Time & $\begin{array}{l}-0.14 \\
(0.08)\end{array}$ & $\begin{array}{l}-0.17 * * \\
(0.05)\end{array}$ & $\begin{array}{l}-0.13^{* *} \\
(0.04)\end{array}$ & $\begin{array}{l}-0.09 * * \\
(0.02)\end{array}$ & $\begin{array}{l}-0.17 \\
(0.09)\end{array}$ & $\begin{array}{l}-0.18 * * \\
(0.06)\end{array}$ & $\begin{array}{l}-0.11 * * \\
(0.03)\end{array}$ & $\begin{array}{l}-0.05^{*} \\
(0.02)\end{array}$ \\
\hline (8) & $\begin{array}{l}\text { Trend Breaks (coefficient } \\
\text { reported is trend break) }\end{array}$ & $\begin{array}{l}-0.06^{* *} \\
(0.02)\end{array}$ & $\begin{array}{l}-0.04 \\
(0.02)\end{array}$ & $\begin{array}{l}-0.00 \\
(0.01)\end{array}$ & $\begin{array}{l}0.00 \\
(0.01)\end{array}$ & $\begin{array}{l}-0.06^{* *} \\
(0.02)\end{array}$ & $\begin{array}{l}-0.02 \\
(0.02)\end{array}$ & $\begin{array}{l}0.01 \\
(0.02)\end{array}$ & $\begin{array}{l}0.01 \\
(0.01)\end{array}$ \\
\hline & State-specific time trends & $\mathrm{n}$ & $\mathrm{y}$ & $\mathrm{n}$ & $\mathrm{y}$ & $\mathrm{n}$ & $\mathrm{y}$ & $\mathrm{n}$ & $\mathrm{y}$ \\
\hline & Balanced Panel & $\mathrm{n}$ & $\mathrm{n}$ & $\mathrm{y}$ & $\mathrm{y}$ & $\mathrm{n}$ & $\mathrm{n}$ & $\mathrm{y}$ & $\mathrm{y}$ \\
\hline & Restrict to Post-1974 & $\mathrm{n}$ & $\mathrm{n}$ & $\mathrm{n}$ & $\mathrm{n}$ & $\mathrm{y}$ & $\mathrm{y}$ & $\mathrm{y}$ & $\mathrm{y}$ \\
\hline
\end{tabular}

$*$ significant at $5 \% ; *$ significant at $1 \%$

Note - See text in Section V for more details. The data consists of a gency-year level observations (except for the third row, which is state-year level). Standard errors reported in parentheses a re clustered at the state level to allow for intra-state correlation in error structure. State and year effects a re included in all specifications. Controls include manda tory minimum law dummy, poverty ra te, unemployment rate, racial composition, a ge composition, lagged police population share, and lagged imprisoned population share. All point estimates are on for the impact of add-on gun laws within three years of the effective date. Unless otherwise noted, dependant va riable is log gun robberies per 100,000 residents, and independant variable is a dummy that is one within 3 years after the add-on gun laws effective date and zero otherwise. Exceptions: Outcome in row 1 is gun robberies oer 100,000 residents. Outcome in row 5 is log gun robberies. Coefficients for row 8 (trend breaks) are on post-add-on*rela tive time interaction. 
Table 9: Triple Difference: Impact of Add-on Term

\begin{tabular}{lllllllll}
\hline \hline & \multicolumn{7}{c}{ Annual Reported Gun Robberies per 100,000 residents } \\
& $(1)$ & $(2)$ & $(3)$ & $(4)$ & $(5)$ & $(6)$ & $(7)$ & $(8)$ \\
\hline $\begin{array}{l}\text { Within one year post add- } \\
\text { on law effective date*add- }\end{array}$ & $-0.04^{*}$ & -0.03 & -0.00 & $-0.07^{*}$ & $-0.03^{*}$ & -0.03 & -0.05 & -0.05 \\
$\begin{array}{l}\text { on term } \\
\text { Within two years post }\end{array}$ & $(0.02)$ & $(0.02)$ & $(0.03)$ & $(0.03)$ & $(0.01)$ & $(0.01)$ & $(0.02)$ & $(0.03)$ \\
add-on law effective & $-0.04^{*}$ & -0.03 & 0.01 & -0.06 & $-0.03^{*}$ & -0.02 & -0.03 & -0.04 \\
date*add-on term & $(0.02)$ & $(0.02)$ & $(0.03)$ & $(0.03)$ & $(0.01)$ & $(0.01)$ & $(0.03)$ & $(0.04)$ \\
Within three years post & & & & & & & & -0.03 \\
add-on law effective & -0.04 & -0.02 & 0.03 & -0.05 & $-0.03 *$ & -0.02 & -0.02 & $(0.04)$ \\
date*add-on term & $(0.02)$ & $(0.02)$ & $(0.04)$ & $(0.04)$ & $(0.01)$ & $(0.01)$ & $(0.03)$ & $(0.03)$ \\
& & & & & & & & \\
State-specific time trends & $\mathrm{n}$ & $\mathrm{y}$ & $\mathrm{n}$ & $\mathrm{y}$ & $\mathrm{n}$ & $\mathrm{y}$ & $\mathrm{n}$ & $\mathrm{y}$ \\
$\begin{array}{l}\text { Balanced Panel } \\
\text { Restrict to Post-1974 }\end{array}$ & $\mathrm{n}$ & $\mathrm{n}$ & $\mathrm{y}$ & $\mathrm{y}$ & $\mathrm{n}$ & $\mathrm{n}$ & $\mathrm{y}$ & $\mathrm{y}$ \\
\hline $\begin{array}{l}\text { Observations } \\
\text { R-squared }\end{array}$ & 7839 & $\mathrm{n}$ & $\mathrm{n}$ & $\mathrm{n}$ & $\mathrm{y}$ & $\mathrm{y}$ & $\mathrm{y}$ & $\mathrm{y}$ \\
\hline
\end{tabular}

$*$ significant at $5 \% ; *$ significant at $1 \%$

Note - The data consists of agency-year level observations. Standard errors reported in parentheses are clustered at the state level to allow for intra-state correlation in error structure. State and year effects are included in all specifications. Controls include manda tory minimum law dummy, poverty rate, unemployment rate, racial composition, age composition, lagged police population share, and lagged imprisoned population share.

Table 10: Lagged Dependant Variable Specification

\begin{tabular}{lllll}
\hline \hline & \multicolumn{5}{c}{ Annual Reported Gun Robberies per 100,000 residents } \\
& $(1)$ & $(2)$ & $(3)$ & $(4)$ \\
\hline Within one year post add-on & -0.15 & -0.05 & -0.01 & 0.01 \\
law effective date & $(0.09)$ & $(0.04)$ & $(0.19)$ & $(0.05)$ \\
& & & & \\
Within two years post add-on & $-0.19^{* *}$ & $-0.10^{* *}$ & -0.13 & $-0.10^{*}$ \\
law effective date & $(0.06)$ & $(0.03)$ & $(0.13)$ & $(0.04)$ \\
& & & & \\
Within three years post add- & -0.12 & -0.08 & -0.09 & -0.06 \\
on law effective date & $(0.06)$ & $(0.04)$ & $(0.11)$ & $(0.06)$ \\
& & & & \\
Balanced Panel & $\mathrm{n}$ & $\mathrm{y}$ & $\mathrm{n}$ & $\mathrm{y}$ \\
Restrict to Post-1974 & $\mathrm{n}$ & $\mathrm{n}$ & $\mathrm{y}$ & $\mathrm{y}$ \\
\hline Observations & 1405 & 290 & 1107 & 185 \\
Arellano-Bond test for AR(1) & 0 & .001 & 0 & .016 \\
Arellano-Bond test for AR(2) & .436 & .979 & .583 & .629 \\
Hansen over-ID test & 1.00 & 1.00 & 1.00 & 1.00 \\
\hline
\end{tabular}

$*$ significant at $5 \% ; *$ significant at $1 \%$

Note - The data consists of state-year level observations. Arellano-Bond dynamic panel estimates, one-step difference GMM results are reported. All available lagged differences of $\log$ gun robberies were used. The following were used as exogenous instruments: mandatory minimum law dummy, poverty rate, unemployment rate, racial composition, age composition, lagged police population share, and lagged imprisoned population share. Robust standard errors in parentheses. Hansen J statistic for overidentifying restrictions, and Arellano-Bond tests for autocorrelation are reported. 


\section{Table 11: Monte Carlo Standard Error Calculation \\ State level Data}

Panel A: One year Impact

\begin{tabular}{|c|c|c|c|c|c|c|c|c|c|c|}
\hline & \multicolumn{5}{|c|}{$\begin{array}{l}\text { Monthly Reported Gun Robberies per } \\
100,000 \text { residents }\end{array}$} & \multicolumn{5}{|c|}{$\begin{array}{l}\text { Monthly Log Reported Gun } \\
\text { Robberies per } 100,000 \text { residents }\end{array}$} \\
\hline & (1) & (2) & (3) & (4) & $(5)$ & (6) & (7) & (8) & (9) & (10) \\
\hline \multicolumn{11}{|l|}{ Post Add-on Law } \\
\hline Effective Date & -1.68 & -1.61 & -1.19 & -0.59 & -1.28 & -0.20 & -0.19 & -0.16 & -0.09 & -0.07 \\
\hline Robust standard errors & $(0.52)^{* *}$ & $(0.57)$ & $(0.53)^{*}$ & $(0.25)^{*}$ & $(0.60)^{*}$ & $(0.06)^{* *}$ & $(0.06)^{* *}$ & $(0.06)^{*}$ & $(0.03)^{*}$ & $(0.07)$ \\
\hline Placebo standard errors & {$[1.00]$} & {$[1.02]$} & {$[0.99]$} & {$[0.83]$} & {$[0.79]^{*}$} & {$[0.10]$} & {$[0.10]$} & {$[0.10]$} & {$[0.10]^{*}$} & [0.10] \\
\hline State Fixed Effects & $\mathrm{n}$ & $\mathrm{n}$ & $\mathrm{n}$ & $\mathrm{y}$ & $\mathrm{n}$ & $\mathrm{n}$ & $\mathrm{n}$ & $\mathrm{n}$ & $\mathrm{y}$ & $\mathrm{n}$ \\
\hline Time Trend & $\mathrm{n}$ & $\mathrm{y}$ & $\mathrm{y}$ & $\mathrm{n}$ & $\mathrm{n}$ & $\mathrm{n}$ & $\mathrm{y}$ & $\mathrm{y}$ & $\mathrm{n}$ & $\mathrm{n}$ \\
\hline Post-74 Dummy & $\mathrm{n}$ & $\mathrm{n}$ & $\mathrm{y}$ & $\mathrm{n}$ & $\mathrm{n}$ & $\mathrm{n}$ & $\mathrm{n}$ & $\mathrm{y}$ & $\mathrm{n}$ & $\mathrm{n}$ \\
\hline Year Dummies & $\mathrm{n}$ & $\mathrm{n}$ & $\mathrm{n}$ & $\mathrm{n}$ & $\mathrm{y}$ & $\mathrm{n}$ & $\mathrm{n}$ & $\mathrm{n}$ & $\mathrm{n}$ & $\mathrm{y}$ \\
\hline Balanced Panel & $\mathrm{y}$ & $\mathrm{y}$ & $\mathrm{y}$ & $\mathrm{y}$ & $\mathrm{y}$ & $\mathrm{y}$ & $\mathrm{y}$ & $\mathrm{y}$ & $\mathrm{y}$ & $\mathrm{y}$ \\
\hline Observations & 576 & 576 & 576 & 576 & 576 & 573 & 573 & 573 & 573 & 573 \\
\hline R-squared & 0.48 & 0.51 & 0.63 & 0.88 & 0.74 & 0.51 & 0.53 & 0.59 & 0.88 & 0.64 \\
\hline
\end{tabular}

\section{Panel B: Two year Impact}

\begin{tabular}{|c|c|c|c|c|c|c|c|c|c|c|}
\hline & \multicolumn{5}{|c|}{$\begin{array}{l}\text { Monthly Reported Gun Robberies per } \\
100,000 \text { residents }\end{array}$} & \multicolumn{5}{|c|}{ Monthly Log Reported Gun } \\
\hline & $(1)$ & $(2)$ & (3) & (4) & $(5)$ & (6) & (7) & (8) & (9) & $(10)$ \\
\hline \multicolumn{11}{|l|}{ Post Add-on Law } \\
\hline Effective Date & $-2.72 * *$ & $-2.53 * *$ & $-1.86^{*}$ & $-0.97 *$ & -1.50 & $-0.34 * *$ & $-0.31 * *$ & $-0.24 * *$ & $-0.17 * *$ & -0.11 \\
\hline Robust standard errors & $(0.64)^{* *}$ & $(0.68)^{* *}$ & $(0.67)^{*}$ & $(0.35)^{*}$ & $(0.83)$ & $(0.09)^{* *}$ & $(0.08) * *$ & $(0.08)^{* *}$ & $(0.04)^{* *}$ & $(0.08)$ \\
\hline Placebo standard errors & {$[1.03]$} & {$[1.12]$} & {$[1.07]$} & {$[0.86]$} & {$[0.97]^{*}$} & {$[0.12]^{*}$} & {$[0.13]^{*}$} & {$[0.12]^{*}$} & {$[0.10]^{*}$} & [0.14] \\
\hline State Fixed Effects & $\mathrm{n}$ & $\mathrm{n}$ & $\mathrm{n}$ & $\mathrm{y}$ & $\mathrm{n}$ & $\mathrm{n}$ & $\mathrm{n}$ & $\mathrm{n}$ & $\mathrm{y}$ & $\mathrm{n}$ \\
\hline Time Trend & $\mathrm{n}$ & $\mathrm{y}$ & $\mathrm{y}$ & $\mathrm{n}$ & $\mathrm{n}$ & $\mathrm{n}$ & $\mathrm{y}$ & $\mathrm{y}$ & $\mathrm{n}$ & $\mathrm{n}$ \\
\hline Post-74 Dummy & $\mathrm{n}$ & $\mathrm{n}$ & $\mathrm{y}$ & $\mathrm{n}$ & $\mathrm{n}$ & $\mathrm{n}$ & $\mathrm{n}$ & $\mathrm{y}$ & $\mathrm{n}$ & $\mathrm{n}$ \\
\hline Year Dummies & $\mathrm{n}$ & $\mathrm{n}$ & $\mathrm{n}$ & $\mathrm{n}$ & $\mathrm{y}$ & $\mathrm{n}$ & $\mathrm{n}$ & $\mathrm{n}$ & $\mathrm{n}$ & $\mathrm{y}$ \\
\hline Balanced Panel & $\mathrm{y}$ & $\mathrm{y}$ & $\mathrm{y}$ & $\mathrm{y}$ & $\mathrm{y}$ & $\mathrm{y}$ & $\mathrm{y}$ & $\mathrm{y}$ & $\mathrm{y}$ & $\mathrm{y}$ \\
\hline Observations & 1152 & 1152 & 1152 & 1152 & 1152 & 1147 & 1147 & 1147 & 1147 & 1147 \\
\hline R-squared & 0.49 & 0.52 & 0.61 & 0.85 & 0.69 & 0.49 & 0.52 & 0.58 & 0.86 & 0.66 \\
\hline
\end{tabular}

\section{Panel C: Three year Impact}

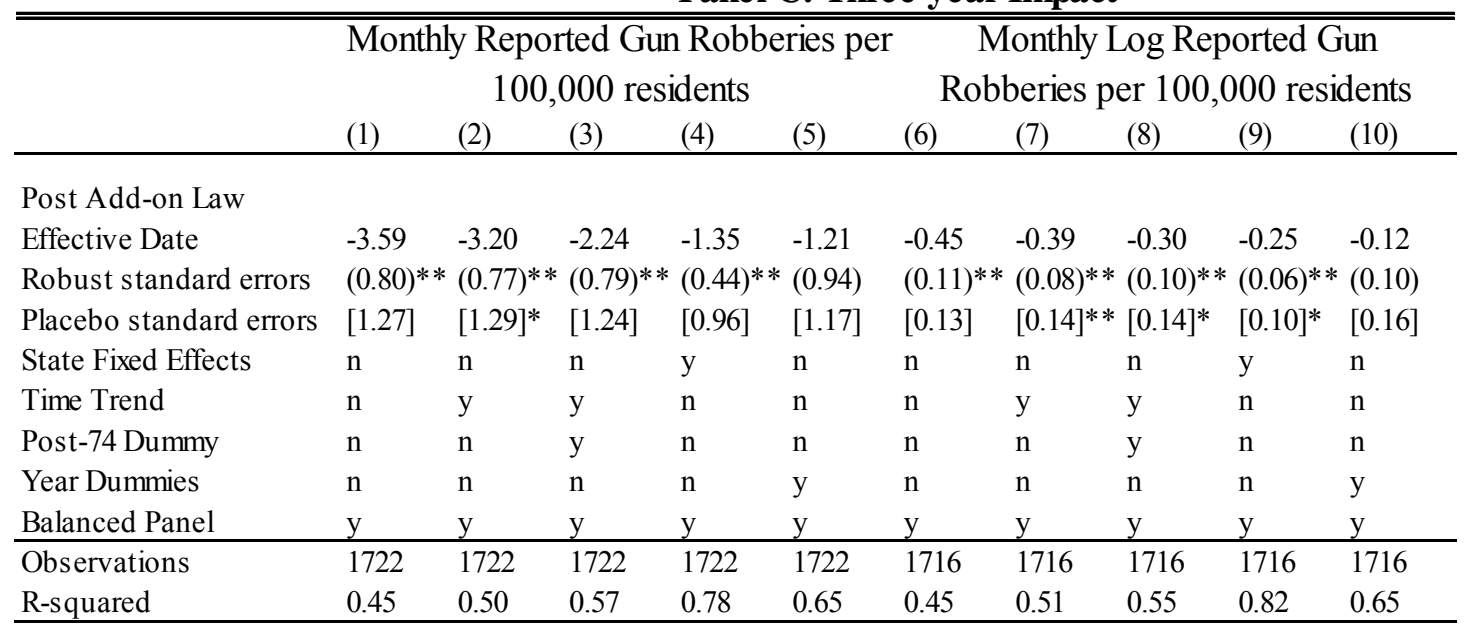

* significant at $5 \% ; * *$ significant at $1 \%$

Note - The data consists of state-month levelobservations. Standard errors reported in parentheses are clustered at the state level to allow for intra-state correlation in error structure. Controls include poverty rate, unemployment rate, ra cialcomposition, age composition, lagged police population share, and la gged imprisoned population share. The calculation method for bootstrap standard errors in brackets is described in the text. 